В.Т. Ивашкин ${ }^{1}$, И.В. Маев$^{2}$, Д.И. Абдулганиева ${ }^{3}$, С.А. Алексеенко ${ }^{4}$, А.В. Горелов ${ }^{1,5}$, И.Н. Захарова ${ }^{6}$, О.Ю. Зольникова ${ }^{1}$, Н.Ю. Ивашкина ${ }^{6}$, Н.В. Корочанская ${ }^{7}$, С.Н. Маммаев ${ }^{8}$, Е.А. Полуэктова ${ }^{1}$, А.С. Трухманов ${ }^{1}$, Д.В. Усенко ${ }^{6}$ Ю.П. Успенский ${ }^{9}$, В.В. Цуканов ${ }^{10}$, О.С. Шифринн ${ }^{1}$, И.В. Бережная ${ }^{6}$, К.В. Ивашкин ${ }^{1}$, Т.Л. Лапина ${ }^{1}$, Р.В. Масленников ${ }^{1}$, С.В. Николаева ${ }^{5}$, Н.Г. Сугян ${ }^{6}$, А.И. Ульянин ${ }^{1, *}$

1 ФГАОУ ВО «Первый Московский государственный университет им. И.М. Сеченова» (Сеченовский университет) Министерства здравоохранения Российской Федеращии, Москва, Российская Федерачия

${ }^{2}$ ФГБОУ ВО «Московский государственный медико-стоматологический университет им. А.И. Евдокимова»

Министерства здравоохранения Российской Федеращии, Москва, Российская Федерация

${ }^{3}$ ФГБОУ ВО «Казанский государственный медицинский университет» Министерства здравоохранения

Российской Федерации, Казань, Российская Федеращия

${ }^{4}$ ГБОУ ВПО «Дальневосточный государственный медицинский университет» Министерства здравоохранения

Российской Федеращии, Хабаровск, Российская Федеращия

${ }_{5}^{5}$ ФБУН «Центральный НИИ эпидемиологии» Роспотребнадзора, Москва, Российская Федерация

${ }^{6}$ ФГБОУ ДПО «Российская медицинская академия непрерывного профессионального образования»

Министерства здравоохранения Российской Федеращии, Москва, Российская Федерачия

${ }^{7}$ ГБОУ ВПО «Кубанский государственный медицинский университет» Министерства здравоохранения Российской Федерации, Краснодар, Российская Федерация

${ }^{8}$ ФГБОУ ВО «Дагестанский государственный медицинский университет» Министерства здравоохранения

Российской Федерачии, Махачкала, Российская Федерачия

${ }_{9}^{9}$ ФГБОУ ВО «Санкт-Петербургский государственный педиатрический медицинский университет»

Министерства здравоохранения Российской Федеращии, Санкт-Петербург, Российская Федерация

${ }^{10}$ ФБГНУ «Федеральный исследовательский центр “Красноярский научный иентр Сибирского отделения Российской академии наук” , обособленное подразделение НИИ медицинких проблем Севера, Красноярск, Российская Федерация

Цель представления практических рекомендаций, предназначенных для врачей первичного звена здравоохранения, терапевтов, педиатров, гастроэнтерологов и врачей общей практики, - улучшить результаты лечения и профилактики заболеваний гастроэнтерологического профиля у взрослых и детей при назначении пробиотиков, пребиотиков, синбиотиков и обогащенных ими функциональных пищевых продуктов.

Основное содержание. Пробиотики - это живые микроорганизмы, которые приносят пользу здоровью организма хозяина при введении в адекватных количествах. К пребиотикам относят не перевариваемые пищеварительными ферментами человека, но ферментируемые кишечной микробиотой субстанции, которые приводят к специфическим изменениям в составе и/или активности кишечной микробиоты, принося таким 
образом пользу здоровью организма хозяина. В качестве механизма действия пробиотиков рассмотрены поддержание колонизационной резистентности, метаболизм пищевых субстратов и утилизация конечных метаболитов, продукция субстратов, необходимых для макроорганизма, а также регуляция местного и адаптивного иммунного ответа. Требования к реализации на территории Российской Федерации дифференцированы для биологически активных добавок к пище (БАД), лекарственных средств (ЛС) и функциональных пищевых продуктов (ФПП). Представлен обзор пробиотических штаммов, зарегистрированных на территории РФ в качестве БАД, ЛС, ФПП, а также рекомендации по применению данных штаммов для лечения и профилактики заболеваний гастроэнтерологического профиля у детей и взрослых.

Заключение. Клиническая эффективность пробиотиков, пребиотиков, синбиотиков и обогащенных ими функциональных пищевых продуктов зависит от входящих в их состав пробиотических штаммов и пребиотиков и подтверждается путем сравнительного анализа результатов надлежащих клинических исследований. Не во всех пробиотиках, зарегистрированных на территории РФ в качестве БАД, ЛС и ФП, идентифицирован штамм, что не гарантирует развитие ожидаемого клинического эффекта. Законодательный механизм регулирования ФПП требует совершенствования регламента оборота и контроля терапевтической эффективности.

Ключевые слова: пробиотик, пробиотический штамм, пребиотик, синбиотик, функциональный пищевой продукт, функциональный пищевой ингредиент, острая диарея, антибиотикоассоциированная диарея, C. difficile-ассоциированная болезнь, эрадикация H. pylori, воспалительные заболевания кишечника, язвенный колит, болезнь Крона, паучит, синдром раздраженного кишечника, функциональный запор, функциональная диспепсия, профилактика диареи, печеночная энцефалопатия, гастроэнтерит

Конфликт интересов: авторы заявляют об отсутствии конфликта интересов.

Для цитирования: Ивашкин В.Т., Маев И.В., Абдулганиева Д.И., Алексеенко С.А., Горелов А.В., Захарова И.Н., Зольникова О.Ю., Ивашкина Н.Ю., Корочанская Н.В., Маммаев С.Н., Полуэктова Е.А., Трухманов А.С., Усенко Д.В., Успенский Ю.П., Цуканов В.В., Шифрин О.С., Бережная И.В., Ивашкин К.В., Лапина Т.Л., Масленников Р.В., Николаева С.В., Сугян Н.Г., Ульянин А.И. Практические рекомендации Научного сообщества по содействию клиническому изучению микробиома человека (НСОИМ) и Российской гастроэнтерологической ассоциации (РГА) по применению пробиотиков, пребиотиков, синбиотиков и обогащенных ими функциональных пищевых продуктов для лечения и профилактики заболеваний гастроэнтерологического профиля у детей и взрослых. Российский журнал гастроэнтерологии, гепатологии, колопроктологии. 2021;31(2):65-91. https://doi.org/10.22416/1382-4376-2021-31-2-65-91

\section{Practical Recommendations of Scientific Society for the Study of Human Micro- biome and the Russian Gastroenterological Association on Use of Probiotics, Prebiotics, Synbiotics and Functional Foods in Treatment and Prevention of Gas- troenterological Diseases in Children and Adults}

Vadimir T. Ivashkin ${ }^{1}$, Igor V. Mayev², Diana I. Abdulganieva ${ }^{3}$, Sergey A. Alekseenko ${ }^{4}$, Alexander V. Gorelov ${ }^{1,5}$, Irina N. Zakharova ${ }^{6}$, Oxana Yu. Zolnikova ${ }^{1}$, Natalia Yu. Ivashkina ${ }^{6}$, Natalia V. Korochanskaya ${ }^{7}$, Suleyman N. Mammaev ${ }^{8}$, Elena A. Poluektova ${ }^{1}$, Alexander S. Trukhmanov ${ }^{1}$, Denis V. Usenko ${ }^{6}$, Yury P. Uspensky ${ }^{9}$, Vladislav V. Tsukanov ${ }^{10}$, Oleg S. Shifrin ${ }^{1}$, Irina V. Berezhnaya ${ }^{6}$, Konstantin V. Ivashkin ${ }^{1}$, Tatiana L. Lapina ${ }^{1}$, Roman V. Maslennikov ${ }^{1}$, Svetlana V. Nikolaeva ${ }^{5}$, Narine G. Sugyan ${ }^{6}$, Anatoly I. Ulyanin ${ }^{1, *}$

${ }^{1}$ Sechenov First Moscow State University (Sechenov University), Moscow, Russian Federation

${ }^{2}$ Yevdokimov Moscow State University of Medicine and Dentistry, Moscow, Russian Federation

${ }^{3}$ Kazan State Medical University, Kazan, Russian Federation

${ }^{4}$ Far-Eastern State Medical University, Khabarovsk, Russian Federation

${ }^{5}$ Central Research Institute of Epidemiology, Moscow, Russian Federation

${ }^{6}$ Russian Medical Academy of Continuous Professional Education, Moscow, Russian Federation

${ }^{7}$ Kuban State Medical University, Krasnodar, Russian Federation

${ }^{8}$ Dagestan State Medical University, Makhachkala, Russian Federation

${ }^{9}$ Saint-Petersburg State Pediatric Medical University, St. Petersburg, Russian Federation

${ }^{10}$ Research Institute for Medical Problems in the North - Division of Krasnoyarsk Scientific Centre of the Siberian Branch of the RAS, Krasnoyarsk, Russian Federation

Aim. The practical guidelines are intended for primary care physicians, general practitioners, paediatricians, gastroenterologists and general internists to advance the treatment and prevention of gastroenterological diseases in adults and children in therapies with probiotics, prebiotics, synbiotics and their enriched functional foods.

Key points. Probiotics are live microorganisms that sustain health of the host when supplied in adequate amounts. Prebiotics include human-indigestible but accessible to gut microbiota substances expediting specific changes in the composition and/or activity of gastrointestinal microbiota that favour the host health. The mechanism of probiotic action comprises the quorum resistance maintenance, nutrient substrate metabolism and end metabolite recycling, macroorganism-sustaining substrate production, as well as the mediation of local and adaptive immune responses. 
The Russian Federation regulates market differently for biologically active food additives (BAFA), medicinal products (drugs) and functional food products (FFP). We overview the probiotic strains regulated in Russia as BAFAs, drugs and FFPs and provide recommendations on the use of these strains in treatment and prevention of gastroenterological diseases in children and adults.

Conclusion. The clinical efficacy of probiotics, prebiotics, synbiotics and fortified functional foods depends on the prebiotic and strain properties and is verified in appropriate comparative clinical trials. Not all probiotics registered in Russia as BAFAs, drugs and FFPs have a strain identity, which provides no warranty of the clinical effect expected. The FFP legislation demands improved regulation mechanisms and control for therapeutic efficacy.

Keywords: probiotic, probiotic strain, prebiotic, synbiotic, functional food, functional food ingredient, acute diarrhoea, antibiotic-associated diarrhoea, $C$. difficile-associated disease, $H$. pylori eradication, inflammatory bowel disease, ulcerative colitis, Crohn's disease, pouchitis, irritable bowel syndrome, functional constipation, functional dyspepsia, diarrhoea prevention, hepatic encephalopathy, gastroenteritis

Conflict of interest: the authors declare no conflict of interest.

For citation: Ivashkin V.T., Mayev I.V., Abdulganieva D.I., Alekseenko S.A., Gorelov A.V., Zakharova I.N., Zolnikova O.Yu., Ivashkina N.Yu., Korochanskaya N.V., Mammaev S.N., Poluektova E.A., Trukhmanov A.S., Usenko D.V., Uspensky Y.P., Tsukanov V.V., Shifrin O.S., Berezhnaya I.V., Ivashkin K.V., Lapina T.L., Maslennikov R.V., Nikolaeva S.V., Sugyan N.G., Ulyanin A.I. Practical Recommendations of Scientific Society for the Study of Human Microbiome and the Russian Gastroenterological Association on Use of Probiotics, Prebiotics, Synbiotics and Functional Foods in Treatment and Prevention of Gastroenterological Diseases in Children and Adults. Russian Journal of Gastroenterology, Hepatology, Coloproctology. 2021;31(2):65-91. https://doi.org/10.22416/13824376-2021-31-2-65-91

\section{1. Пробиотики}

\section{1 Определение}

Пробиотики - это живые микроорганизмы, которые приносят пользу здоровью организма хозяина при введении в адекватных количествах [1].

В качестве пробиотиков чаще всего применяются бактерии родов Lactobacillus, Bifidobacterium, Streptococcus и Bacillus, некоторые виды E. coli и грибы рода Saccharomyces [2].

Помимо пробиотиков на здоровье человека также оказывают влияние пребиотики. К пребиотикам относятся не перевариваемые пищеварительными ферментами человека, но ферментируемые кишечной микробиотой субстанции, которые приводят к специфическим изменениям в составе и/или активности желудочно-кишечной микробиоты, принося таким образом пользу здоровью организма хозяина. К наиболее важным группам пребиотиков относят фруктаны (инулин и фруктоолигосахариды), олигосахариды (например, мономеры крахмала) и галактоолигосахариды. Аналогичными с пребиотиками свойствами обладают пищевые волокна, однако они традиционно выделяются в отдельную подгруппу [3].

Продукты, имеющие в своем составе пробиотические штаммы и пребиотики, носят название сuн- $^{-}$ биотиков и обладают свойствами как пробиотика, так и пребиотика [4].

\section{2 Роды, виды и штаммы пробиотических} продуктов

Пробиотический штамм идентифицируется на уровне рода, вида и имеет буквенное, цифровое или буквенно-цифровое обозначение, например Bifidobacterium longum 35624, Lactobacillus rhamnosus GG или Bifidobacterium animalis BB12. Определенный штамм пробиотика должен обладать заявленными эффектами при его применении, которые подтверждены клиническими исследованиями.

\section{3 Механизм действия пробиотических штаммов}

Несмотря на существенное разнообразие и широкое применение пробиотических штаммов, их механизмы действия окончательно не изучены. Функции пробиотиков во многом схожи с таковыми у представителей нормальной кишечной микробиоты человека, однако их эффект может различаться в зависимости от рода, вида или даже штамма. Ниже представлены основные механизмы действия и функции пробиотиков.

\section{Поддержание колонизачионной рези- стентности}

В основе колонизационной резистентности лежит способность пробиотических штаммов предотвращать колонизацию желудочно-кишечного тракта (ЖКТ) условно-патогенными и патогенными микроорганизмами за счет угнетения их активности и способности к размножению вследствие конкуренции за питательные вещества, а также путем синтеза ряда антибактериальных метаболитов, активных в отношении патогенных бактерий (органические кислоты, бактериоцины, амины и т.д.) [5].

\section{Метаболизм пищевых субстратов и ути - лизация конечных продуктов метаболизма человека}

Находясь в просвете кишечника, пробиотики метаболизируют компоненты пищи (например, растительные волокна) и некоторые другие субстанции (например, первичные желчные кислоты) за счет наличия специфических ферментов, отсутствующих у человека. К таким ферментам, в частности, относятся $\beta$-галактозидаза (осуществляет гидролиз $\beta$-галактозидов в моносахариды) 
и гидролаза желчных солей (участвует в деконъюгации желчных кислот и их солей) [6].

\section{Продукция метаболитов, необходимых для макроорганизма}

В процессе своей жизнедеятельности пробиотические штаммы осуществляют синтез метаболитов, которые поступают в системный кровоток и участвуют в поддержании гомеостаза макроорганизма. В первую очередь к таким метаболитам относятся короткоцепочечные жирные кислоты (КЦЖК) - ацетат, пропионат и бутират, которые поддерживают регуляцию энергетического гомеостаза (особенно в колоноцитах), а также служат сигнальными молекулами для клеток иммунной системы, определяя их дифференцировку и противовоспалительную активность [7]. В ходе своей жизнедеятельности пробиотические микроорганизмы также продуцируют различные медиаторы - допамин (участвует в формировании мотивации и поведенческих реакций, является предшественником норадреналина и адреналина), норадреналин (регулирует процессы в центральной нервной системе (ЦНС), ответственные за бодрствование, запоминание, обучение и внимание, серотонин (регулирует желудочно-кишечную секрецию и перистальтику, вазоконстрикцию и психоэмоциональный статус), гамма-аминомасляную кислоту (основной ингибиторный нейротрансмиттер в ЦНС), ацетилхолин (основной медиатор в холинергических нервных путях) и гистамин (медиатор гистаминовых рецепторов в клетках ЦНС, органов ЖКТ, сердечно-сосудистой и дыхательной и иммунной систем) [8].

Кроме этого, пробиотики синтезируют такие незаменимые для макроорганизма метаболиты, как, например, триптофан (незаменимая аминокислота, является предшественником серотонина) [8] и витамины группы В, выполняющие роль коферментов множества биохимических процессов в организме человека - рибофлавин (витамин $\mathrm{B}_{2}$ ), кобаламин (витамин $\mathrm{B}_{12}$ ) и фолиевую кислоту [9].

\section{Регуляция местного и адаптивного им- мунного ответа}

Взаимодействие компонентов пробиотических бактерий с иммунокомпетентными клетками хозяина прямо или опосредованно ведет к активации местного и системного противовоспалительного иммунного ответа за счет стимуляции синтеза противовоспалительных цитокинов (в основном, интерлейкина-4 и интерлейкина-10). Повышенный уровень противовоспалительных цитокинов также определяет направленность дифференцировки регуляторных иммунных клеток (в первую очередь Т-регуляторных лимфоцитов), что проявляется угнетением провоспалительных реакций и поддержанием противовоспалительного иммунного ответа [10].

\section{4 Механизмы действия пребиотиков}

Пребиотики изменяют состав и функцию кишечной микробиоты за счет избирательной стимуляции роста и размножения определенных видов бактерий, выступая для них в роли пищевых субстратов [11]. Например, фруктоолигосахариды и галактоолигосахариды метаболизируются преимущественно представителями родов Actinobacteria, Bacteroidetes и Firmicutes, а крахмал и фруктаны ферментируются бактериями родов Bifidobacterium и Ruminococcus. В результате бактериального метаболизма в толстой кишке образуются КЦЖК, низкомолекулярные соединения (например, метан, сероводород, сульфиды) и другие метаболиты, являющиеся пищевым субстратом для других микроорганизмов [12].

Также при ферментации пребиотиков бактериальными клетками образуются кислоты, которые снижают $\mathrm{pH}$ среды в толстой кишке и влияют на состав и функцию кишечной микробиоты (например, снижается количество Bacteroides и стимулируется образование бутирата представителями Firmicutes) [3].

\section{2. Медицинские требования к пробиотикам, пребиотикам и функциональным пищевым продуктам}

\section{1 Регламент оборота пробиотиков и пребиотиков в РФ}

Пробиотики могут быть зарегистрированы на территории РФ в качестве биологически активных добавок к пище (БАД) и лекарственных средств (ЛС) в соответствии с законодательными актами Российской Федерации. Пребиотики в соответствии с данными актами могут быть зарегистрированы на территории РФ только в качестве БАД. В синбиотиках надлежащей регистрации подлежат все составные компоненты, если они заявлены в качестве биологически активных веществ [13].

Безопасность пробиотиков, зарегистрированных в качестве БАД или ЛС, каждого компонента синбиотиков, а также пребиотиков, зарегистрированных в качестве БАД, должна соответствовать строгим микробиологическим стандартам, которые определяются Едиными санитарно-эпидемиологическими и гигиеническими требованиями к товарам, подлежащим санитарно-эпидемиологическому надзору, и контролируются Роспотребнадзором [14].

Биологически активные добавки к пище (БАД) - это природные и (или) идентичные природным биологически активные вещества, а также пробиотические микроорганизмы, предназначенные для употребления одновременно с пищей или введения в состав пищевой продукции [15]. 
Регистрация пробиотиков, пребиотиков и синбиотиков в качестве БАД включает 3 основных этапа:

- испытание образцов,

- экспертиза документации,

- оформление свидетельства о государственной регистрации.

Испытание данных субстанций необходимо для подтверждения их безопасности и соответствия заявленных и реально присутствующих компонентов. Для реализации пробиотиков, пребиотиков и синбиотиков на территории РФ и Евразийского экономического союза (ЕАЭС) в качестве БАД данные препараты должны соответствовать гигиеническим требованиям безопасности пищевой продукции, установленным в Приложениях 1-3 технического регламента Таможенного союза «О безопасности пищевой продукции» (ТР ТС 021/2011) [16]. Кроме этого, необходимо соответствие гигиеническим требованиям безопасности и пищевой ценности пищевых продуктов согласно Санитарно-эпидемиологическим правилам и нормативам СанПиН 2.3.2.2340-08 [17].

После испытания образцов принимается решение о государственной регистрации БАД с внесением в Единый реестр свидетельств о государственной регистрации, который контролируется Федеральной службой по надзору в сфере защиты прав потребителей и благополучия человека (Роспотребнадзор) [15].

В целях предупреждения действий, вводящих в заблуждение потребителей, Роспотребнадзором утверждена и внесена в Единый реестр систем добровольной сертификации (ДСС) «Система добровольной сертификации биологически активных добавок к пище, пищевых добавок и пищевых продуктов, полученных из генетически модифицированных источников» - в рамках которой предусматривается подтверждение качества продукции в соответствии с постановлением СанПиН 2.3.2.1290-03 «Гигиенические требования к организации производства и оборота биологически активных добавок к пище (БАД)». ДСС для пробиотиков и пребиотиков, зарегистрированных в качестве БАД, подтверждает эффективность и соответствие свойств данных субстанций, декларированных производителем или импортером. Нанесение информации на этикетку БАД (и/или на потребительскую (вторичную) упаковку БАД, инструкцию к применению, вкладыш и т.д.) об эффективности использования пробиотика или пребиотика в качестве БАД возможно только после проведения добровольной сертификации БАД и наличии вышеуказанного сертификата соответствия.

При регистрации пробиотиков и пребиотиков в качестве БАД на территории Российской Федерации, информация на этикетке должна включать:

- надпись: «Биологически активная добавка к пище»;
- название: БАД к пище;

надпись: «Не является лекарством»;

- ингредиентный состав вместе со вспомогательными компонентами;

- форма выпуска и упаковка;

область применения с указанием того, источником каких пищевых биологически активных веществ является БАД;

- процент от адекватного уровня потребления; - дозировка;

рекомендации по применению;

- противопоказания;

условия хранения, срок годности;

- сведения о возможности реализации в аптечных учреждениях и специализированных магазинах или отделах продовольственных магазинов по продаже диетических продуктов;

номер технических условий производства (для отечественных БАД);

- название организации-изготовителя и ее юридический адрес (для импортируемых на территорию РФ продуктов - страна происхождения и наименование фирмы-изготовителя);

номер и дата выдачи свидетельства о государственной регистрации;

- реквизиты и контактный телефон организации, уполномоченной принимать претензии от потребителей.

Регистрация пробиотика в качестве ЛС осуществляется согласно требованиям Федерального закона Российской Федерации № 61-Ф3 «Об обращении лекарственных средств» [18]. Для пробиотиков, зарегистрированных как ЛС, применимы правила оборота ЛС, определенные приказом Министерства здравоохранения Российской Федерации от 11 июля 2017 г. № 403н «Об утверждении правил отпуска лекарственных препаратов для медицинского применения, в том числе иммунобиологических лекарственных препаратов, аптечными организациями, индивидуальными предпринимателями, имеющими лицензию на фармацевтическую деятельность» [19].

Пробиотик, зарегистрированный в качестве ЛС, идентифицируется как иммунобиологический лекарственный препарат, который содержит живые или инактивированные апатогенные микроорганизмы (эубиотики), обладающие антагонистической активностью в отношении патогенных и условно-патогенных бактерий. Такие пробиотики должны соответствовать фармакопейным требованиям получения производственного штамма и его посевного материала для формирования производственной биомассы, а также требованиям качества ЛС для определенной лекарственной формы [20].

Зарегистрированный в качестве ЛС пробиотик должен быть отнесен к определенной фармакотерапевтической группе (пробиотик, эубиотик, противодиарейное средство, пробиотик или эубиотик из группы медицинских иммунобиологических препаратов (МИБП-пробиотик или МИБП-эубиотик)) 
и классифицироваться в соответствии с анатомо-терапевтической химической классификацией (АТХК). Зарегистрированные в качестве ЛС на территории РФ пробиотики имеют следующие коды АТХК: сахаромицеты Boulardii (A07FA02), противодиарейные микроорганизмы (A07FA), лактобациллы (G01AX14), микроорганизмы, продуцирующие молочную кислоту (А07FA01), и микроорганизмы, продуцирующие молочную кислоту, в комбинации с другими препаратами (A07FA51). Некоторые из зарегистрированных в качестве ЛС пробиотиков могут иметь одинаковый состав, но при этом отличаться по АТХК и принадлежности к фармакотерапевтической группе.

\section{2 Регламент оборота функциональных} пищевых продуктов, обогащенных

пробиотиками, пребиотиками и синбиотиками

Пробиотики, пребиотики и синбиотики входят в состав различных функциональных пищевых продуктов.

Функциональный пищевой продукт (ФПП) пищевой продукт, предназначенный для систематического употребления в составе пищевых рационов всеми возрастными группами здорового населения, снижающий риск развития заболеваний, связанных с питанием, сохраняющий и улучшающий здоровье за счет наличия в его составе физиологически функциональных пищевых ингредиентов.

Физиологически функциональный пищевой ингредиент (ФФПИ) - биологически активные и/или физиологически ценные, безопасные для здоровья, имеющие точные физико-химические характеристики ингредиенты, для которых выявлены и научно обоснованы свойства, установлены нормы ежедневного потребления в составе пищевых продуктов, полезные для сохранения и улучшения здоровья: пищевые волокна, витамины, минеральные вещества, полиненасыщенные жирные кислоты, пробиотики, пребиотики или синбиотики [13].

Обеспечение надлежащего качества и безопасности ФПП для детей и взрослых основывается на общих требованиях к пищевым продуктам согласно требованиям Федерального закона «О качестве и безопасности пищевых продуктов» [21, 22].

Однако в Российской Федерации статус продуктов функционального питания регламентируется не строго, несмотря на принятые государственные стандарты ГОСТ Р 55577-2013 и ГОСТ Р 54059-2010, определяющие продукты функциональной направленности. В тексте ГОСТ Р 55577-2013 приведены требования подтверждения того, что эффективность ФПП «обоснована при помощи утвержденных методов доказательной медицины», но без ссылок на утверждающие их нормативно-правовые акты. В Приложениях А и Б к вышеуказанному ГОСТ приведены допустимые фразы для описания продукта в аннотации согласно его составу [23].

ГОСТ Р 54059-2010 утверждает классификацию функциональных пищевых ингредиентов, основанную на их эффектах в отношении организма человека. Согласно предлагаемой классификации, один и тот же ФПИ может быть отнесен к нескольким классам [24]. Производитель, ссылаясь на данный ГОСТ, может выносить данные свойства в аннотацию к функциональному пищевому продукту, отражаемую на потребительской упаковке. Классификация и заявленные для ФПИ эффекты представлены в таблице 1.

Таким образом, законодательный механизм регулирования рынка ФПП требует совершенствования ввиду отсутствия полноценного регламента оборота и контроля терапевтической эффективности функциональных пищевых ингредиентов и продуктов.

\section{2 Дозы, эффективность и безопасность}

\subsection{1 Дозы, эффективность и безопас-} ность пробиотиков

Рекомендуемая минимальная эффективная суточная доза пробиотиков должна составлять $10^{8}-10^{9}$ колониеобразующих единиц (КОЕ) [25], однако эффективная доза пробиотика в сутки может различаться в зависимости от пробиотического штамма и формы выпуска.

Определение оптимальной дозировки должно основываться на результатах клинических исследований, демонстрирующих развитие ожидаемых благоприятных эффектов конкретного штамма пробиотика в указанной дозе.

Сохранение жизнеспособности штаммов в указанном количестве до конца срока годности пробиотика и синбиотика также является необходимым условием для его эффективного применения.

Другим немаловажным фактором, определяющим выживаемость пробиотических микроорганизмов и поступление достаточного количества КОЕ в толстую кишку, является агрессивная среда верхних отделов пищеварительного тракта: высокая кислотность, пищеварительные ферменты и соли желчных кислот [26].

Инструментом скрининга для определения выживаемости потенциальных пробиотиков в верхних отделах ЖКТ служат тесты in vitro, воспроизводящие условия его проксимальных отделов и способные помочь определению оптимального количества КОЕ в пробиотике.

Несмотря на многообразие лекарственных форм (капсула, таблетки, саше, назальные спреи и прочие), преимущественной формой доставки пробиотических штаммов в толстую кишку служат капсулы и микрокапсулы, изготовленные из синтетических, полусинтетических или натуральных полимеров, обеспечивающие сохранность пробиотических штаммов в агрессивной среде верхних отделов пищеварительного тракта и обеспечивающие последовательное их высвобождение на протяжении ЖКТ в метаболически активном состоянии [27, 28]. 
Таблища 1. Классификация пробиотиков и пребиотиков в составе функциональных пищевых ингредиентов

Table 1. Classification of probiotics and prebiotics in functional food ingredients

\begin{tabular}{|c|c|c|c|}
\hline $\begin{array}{l}\text { Обозначение и } \\
\text { наименование } \\
\text { класса }\end{array}$ & Наименование группы & Наименование подгруппы & $\begin{array}{c}\text { Наименование } \\
\text { функционального } \\
\text { пищевого ингредиента } \\
\text { (примеры отдельных } \\
\text { ингредиентов) }\end{array}$ \\
\hline \multirow{6}{*}{$\begin{array}{l}\text { Эффект } \\
\text { метаболизма } \\
\text { субстратов }\end{array}$} & \multirow{2}{*}{$\begin{array}{c}\text { Метаболизм } \\
\text { питательных веществ }\end{array}$} & Снижение уровня усвоения жиров & Пищевые волокна \\
\hline & & Регулирование аппетита & Пищевые волокна \\
\hline & Метаболизм углеводов & Поддержание уровня глюкозы в крови & Пищевые волокна \\
\hline & \multirow{3}{*}{$\begin{array}{c}\text { Устойчивость } \\
\text { организма к } \\
\text { онкологическим } \\
\text { патологиям }\end{array}$} & Молочные железы & Пищевые волокна \\
\hline & & Толстая кишка & Пищевые волокна \\
\hline & & Предстательная железа & Пищевые волокна \\
\hline \multirow{2}{*}{$\begin{array}{l}\text { Эффект } \\
\text { поддержания } \\
\text { деятельности } \\
\text { сердечно- } \\
\text { сосудистой } \\
\text { системы }\end{array}$} & \multirow[b]{2}{*}{ Липидный обмен } & $\begin{array}{c}\text { Поддержание уровня } \\
\text { триацилглицеринов в крови }\end{array}$ & Пищевые волокна \\
\hline & & $\begin{array}{c}\text { Поддержание уровня общего } \\
\text { холестерина, липопротеинов высокой } \\
\text { и низкой плотности в крови }\end{array}$ & Пищевые волокна \\
\hline \multirow{7}{*}{$\begin{array}{l}\text { Эффект } \\
\text { поддержания } \\
\text { деятельности } \\
\text { желудочно- } \\
\text { кишечного } \\
\text { тракта }\end{array}$} & \multirow{3}{*}{$\begin{array}{c}\text { Пищеварение и } \\
\text { функциональное } \\
\text { состояние желудочно- } \\
\text { кишечного тракта }\end{array}$} & $\begin{array}{c}\text { Поддержание и улучшение состояния } \\
\text { слизистой оболочки желудочно- } \\
\text { кишечного тракта } \\
\end{array}$ & Пребиотики \\
\hline & & $\begin{array}{c}\text { Контроль функциональных свойств } \\
\text { кишечной иммунокомпетентной } \\
\text { лимфатической ткани }\end{array}$ & $\begin{array}{c}\text { Пробиотики, пребиотики. } \\
\text { синбиотики }\end{array}$ \\
\hline & & $\begin{array}{c}\text { Обеспечение образования и } \\
\text { ассимиляции короткоцепочечных } \\
\text { жирных кислот }\end{array}$ & Пребиотики. синбиотики \\
\hline & \multirow{2}{*}{$\begin{array}{c}\text { Моторно-эвакуаторная } \\
\text { функция кишечника }\end{array}$} & $\begin{array}{c}\text { Уменьшение времени транзита } \\
\text { пищевой массы } \\
\end{array}$ & Пищевые волокна \\
\hline & & Обеспечение формирования стула & Пищевые волокна \\
\hline & \multirow{2}{*}{$\begin{array}{c}\text { Кишечная } \\
\text { микрофлора }\end{array}$} & $\begin{array}{c}\text { Восстановление микроэкологии } \\
\text { (увеличение популяции и видового } \\
\text { состава нормальной микрофлоры) }\end{array}$ & Пробиотики, синбиотики \\
\hline & & $\begin{array}{c}\text { Избирательная стимуляция роста } \\
\text { и (или) биологической активности } \\
\text { нормальной микрофлоры }\end{array}$ & Пребиотики, синбиотики \\
\hline $\begin{array}{l}\text { Эффект } \\
\text { поддержания } \\
\text { зубной и } \\
\text { костной ткани }\end{array}$ & $\begin{array}{c}\text { Снижение риска } \\
\text { развития кариеса }\end{array}$ & У даление зубного налета & Пищевые волокна \\
\hline \multirow{5}{*}{$\begin{array}{l}\text { Эффект } \\
\text { поддержания } \\
\text { иммунной } \\
\text { системы }\end{array}$} & \multirow{3}{*}{$\begin{array}{l}\text { Иммуно- } \\
\text { корректирующее } \\
\text { действие }\end{array}$} & $\begin{array}{c}\text { Обеспечение системного } \\
\text { иммуномодулирующего действия }\end{array}$ & Пробиотики \\
\hline & & $\begin{array}{c}\text { Поддержание формирования клеток } \\
\text { кишечной иммунной системы }\end{array}$ & Пробиотики, синбиотики \\
\hline & & $\begin{array}{c}\text { Поддержание формирования } \\
\text { иммунных клеток кишечной } \\
\text { лимфоидной системы } \\
\end{array}$ & Пребиотики \\
\hline & \multirow{2}{*}{$\begin{array}{c}\text { Нормализация } \\
\text { функции иммунной } \\
\text { системы при } \\
\text { аллергических } \\
\text { реакциях }\end{array}$} & $\begin{array}{c}\text { Снижение адсорбции аллергенов } \\
\text { в кишечнике }\end{array}$ & $\begin{array}{c}\text { Пищевые волокна, } \\
\text { пребиотики }\end{array}$ \\
\hline & & $\begin{array}{l}\text { Улучшение состояния местного } \\
\text { иммунитета в кишечнике }\end{array}$ & Пребиотики \\
\hline
\end{tabular}

В пробиотиках и синбиотиках последнего поколения пробиотические штаммы могут находиться внутри капсулы в виде биопленок. Такая форма сохране- ния штаммов увеличивает срок годности пробиотика, а также обеспечивает высвобождение достаточного количества КОЕ непосредственно в толстой кишке [29]. 
Необходимо отметить, что некоторые пробиотики и синбиотики, выпускающиеся в иных формах (порошки, растворы, саше и пр.) и в составе функциональных пищевых продуктов, доказали свою эффективность и безопасность в надлежащих клинических исследованиях.

Пробиотики характеризуются высокой безопасностью: значительно чаще наблюдается полезный эффект, нежели развитие побочных эффектов. На сегодняшний день сообщается о единичных случаях холангита, бактериемии, сепсиса или эндокардита, вызванных приемом пробиотиков, однако риск развития данных побочных эффектов крайне низок и аналогичен риску заражения штаммами комменсальных бактерий [30].

\subsection{2 Дозы, эффективность и безопас- ность пребиотиков}

Аналогично с пробиотиками, оптимальная эффективная суточная доза пребиотика должна основываться на результатах клинических исследований надлежащего качества, демонстрирующих безопасность и развитие ожидаемых благоприятных эффектов пребиотика в указанной дозе и форме выпуска (капсула, порошок или компонент функционального пищевого продукта).

Пребиотические субстанции характеризуются высокой сохранностью при прохождении через ЖКТ человека, поскольку их ферментация происходит только в толстой кишке с участием кишечной микробиоты и не зависит от активности пищеварительных ферментов человека.

Предполагается, что у пребиотиков отсутствуют опасные для жизни или серьезные побочные эффекты. Однако при употреблении пребиотиков возможно развитие осмотической диареи и метеоризма в связи с реализацией их осмотических свойств в толстой кишке. Основными характеристиками, определяющими развитие данных побочных эффектов, являются доза пребиотика и длина цепи пребиотических субстанций. Более короткие молекулы (например, инулин) метаболизируются быстро и преимущественно в проксимальном отделе толстой кишки, а более длинные цепи (например, пищевые волокна и полисахариды), напротив, ферментируются медленнее и преимущественно в дистальном отделе толстой кишки, что увеличивает риск развития побочных эффектов. Предполагается, что вышеуказанные побочные эффекты пребиотиков могут быть вызваны даже при их употреблении в терапевтических дозах [3].

\section{3. Обзор пробиотических штаммов \\ и пребиотиков, зарегистрированных в РФ}

К пробиотическим штаммам, зарегистрированным на территории РФ в качестве БАД, в состав активных веществ которых не входят иммуноглобулины, метаболиты (в том числе нуклеотиды) или продукты жизнедеятельности микроорганизмов, относятся бактерии родов Lactobacillus, Bifidobacterium, Enterococcus, Pediococcus, Lactococcus, Propionibacterium, Streptococcus и грибы рода Saccharomyces. Основными пребиотиками, зарегистрированными в Российской Федерации в качестве компонентов БАД (в составе пребиотиков или синбиотиков), являются галактоолигосахариды, инулин, лактулоза, олигофруктоза, полисахариды, фруктоолигосахариды и пищевые волокна.

Пробиотики и синбиотики, в составе которых содержатся данные микроорганизмы и пребиотики, перечислены в «Едином реестре свидетельств о государственной регистрации» и разрешены к реализации на территории РФ по состоянию на февраль 2021 года (табл. 2 и 3). В настоящем обзоре приведены лишь пробиотические штаммы в составе синбиотиков, в которых пребиотические субстанции зарегистрированы в качестве биологически активных веществ.

Пробиотики, зарегистрированные на территории РФ в качестве ЛС, представлены бактериями рода Lactobacillus, Bifidobacterium, Escherichia и Enterococcus, а также грибками рода Saccharomyces (табл. 4).

Пробиотики и пребиотики, зарегистрированные на территории РФ в составе пищевых продуктов функционального направления и внесенные Единый реестр свидетельств о государственной регистрации, представлены бактериями рода Lactobacillus, Bifidobacterium, Enterococcus и Streptococcus (табл. 5).

\section{4. К линическое применение}

Не все пробиотики, синбиотики и обогащенные ими функциональные пищевые продукты имеют указание штамма, вне зависимости от принадлежности к БАД или к ЛС. В таком случае развитие ожидаемого эффекта от пробиотика или синбиотика не гарантировано.

Однако следует отметить, что эффективность и безопасность отдельных пробиотических составов, синбиотиков и функциональных пищевых продуктов, содержащих определенные пробиотические микроорганизмы без указания штаммов, доказаны при тех или иных нозологических формах в клинических исследованиях надлежащего качества.

\section{1 Уровни доказательности}

Определение эффективности определенного пробиотического штамма при тех или иных заболеваниях или состояниях осуществляется путем сравнительного анализа результатов надлежащих клинических исследований [31].

Эффективность клинического применения пробиотиков, пребиотиков, синбиотиков 


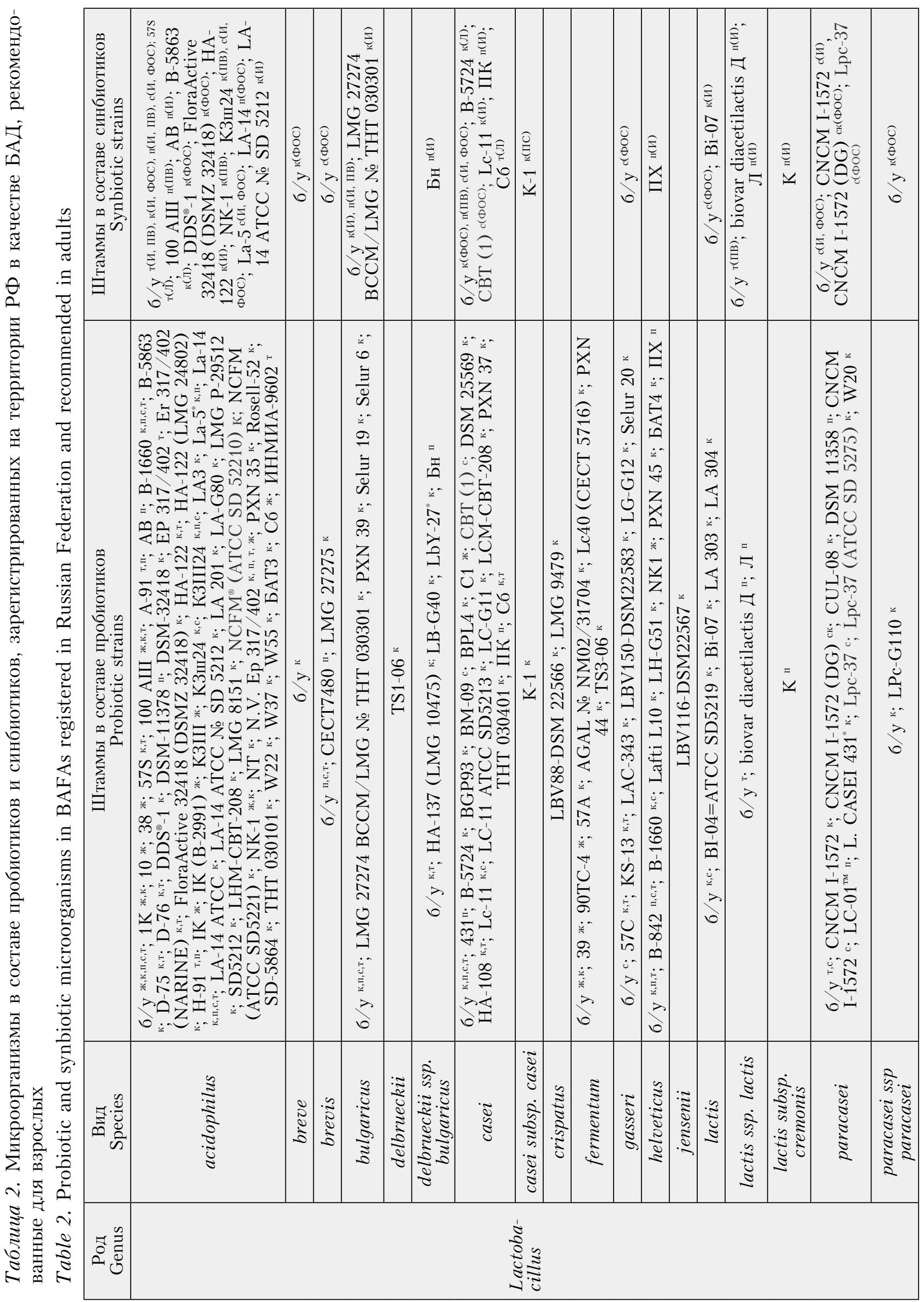




\begin{tabular}{|c|c|c|c|c|c|c|c|c|c|c|c|c|c|c|c|c|}
\hline 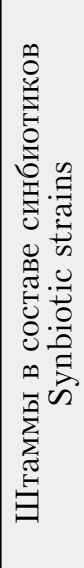 & 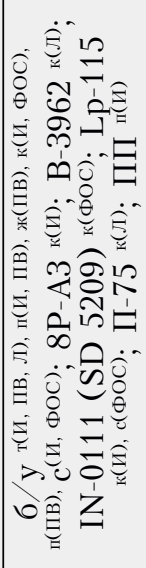 & $\begin{array}{l}\hat{\theta} \\
\underline{o} \\
\lambda \\
0\end{array}$ & 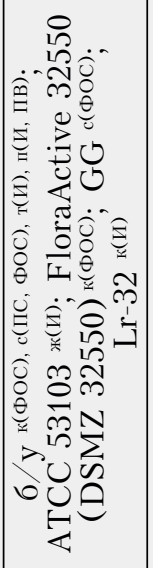 & 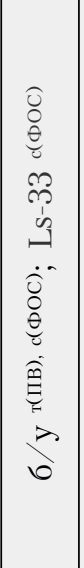 & & & & & & 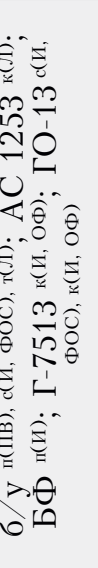 & & 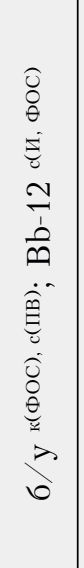 & 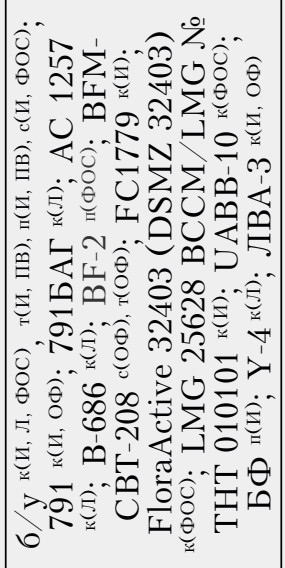 & 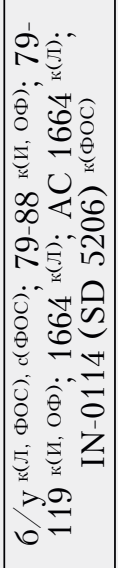 & 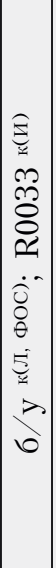 & 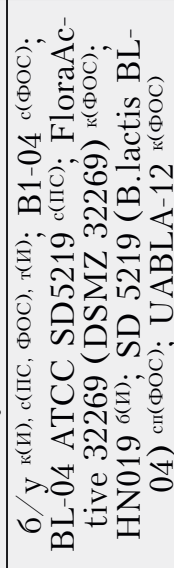 \\
\hline 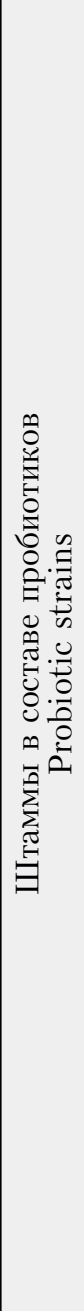 & 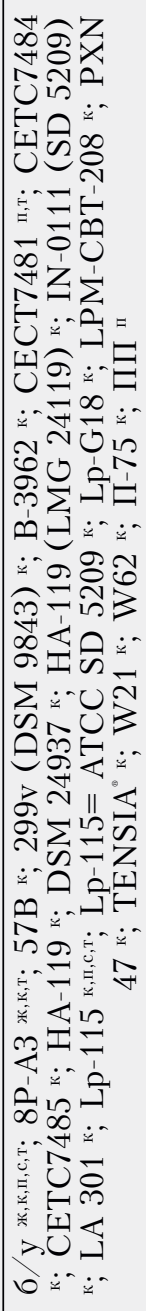 & 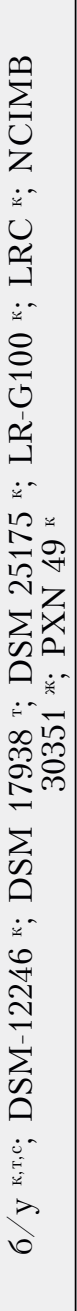 & 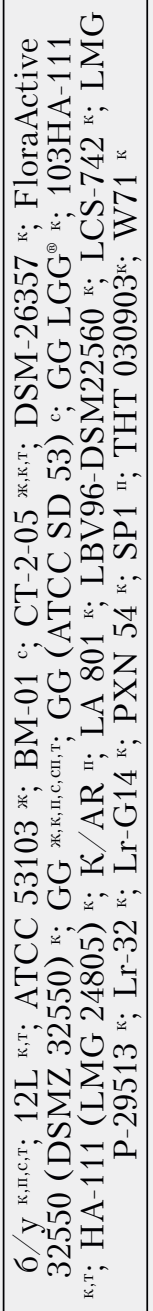 & 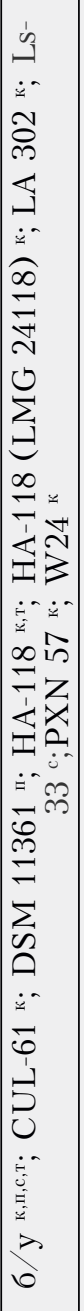 & $\begin{array}{l}2 \\
8 \\
0 \\
\dot{1} \\
1\end{array}$ & 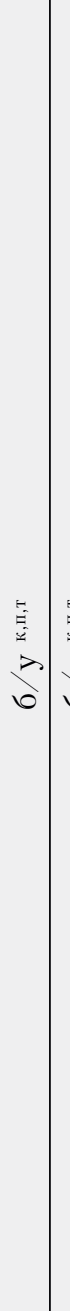 & 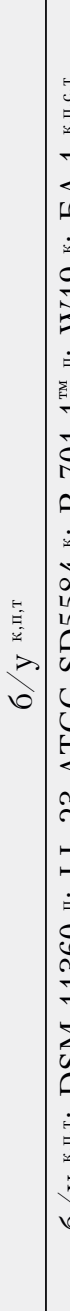 & 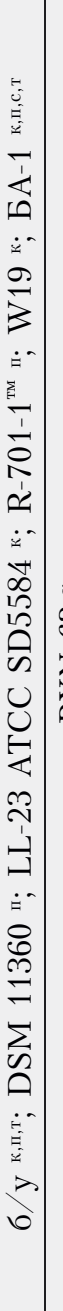 & 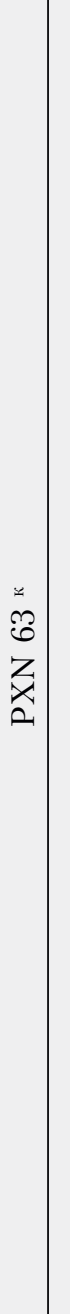 & 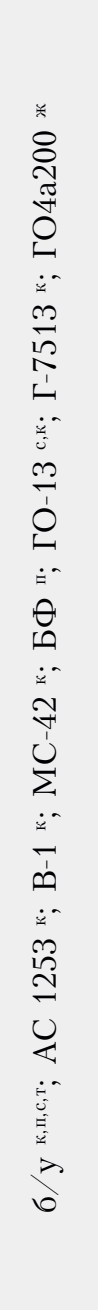 & 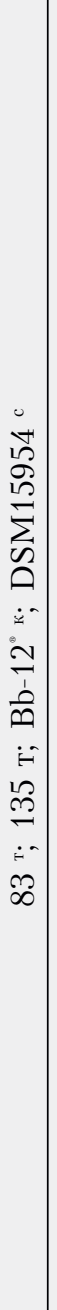 & 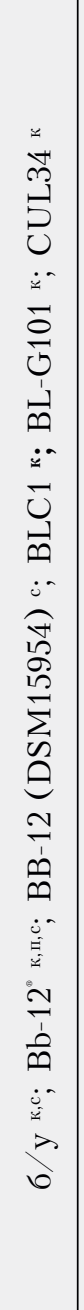 & 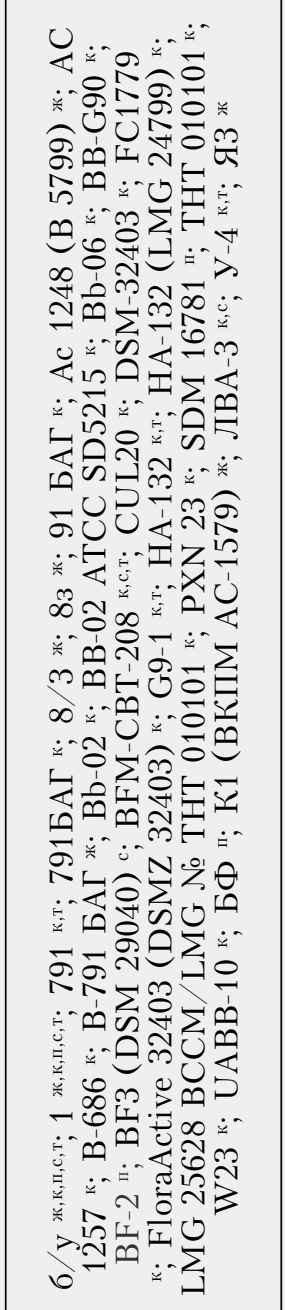 & 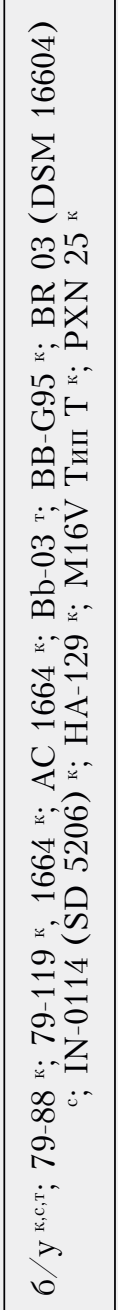 & 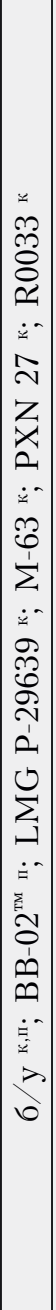 & 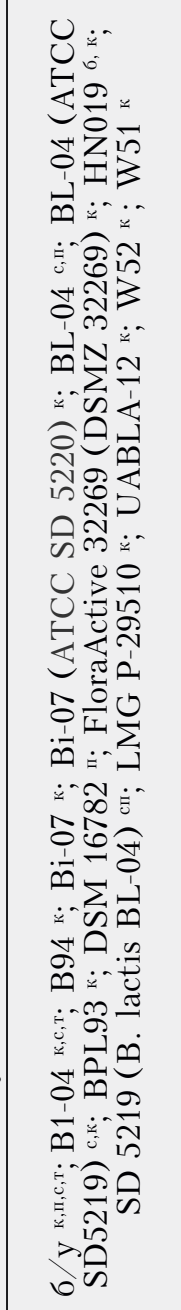 \\
\hline 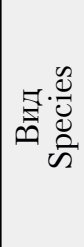 & $\frac{\sqrt{3}}{\frac{3}{3}}$ & 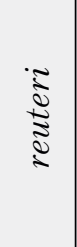 & 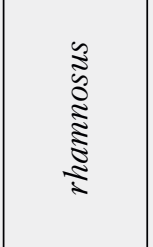 & 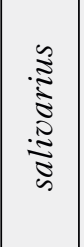 & 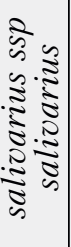 & 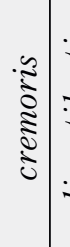 & 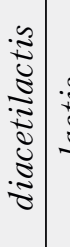 & 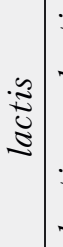 & 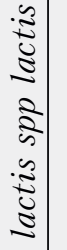 & 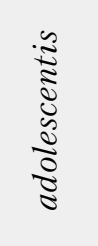 & 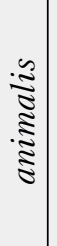 & 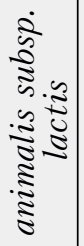 & 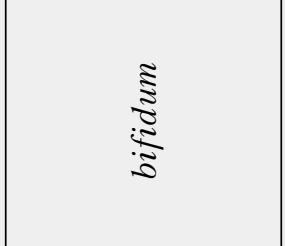 & $\begin{array}{l}5 \\
0 \\
0 \\
0\end{array}$ & 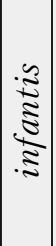 & $\underset{\tilde{\Xi}}{\tilde{\Xi}}$ \\
\hline 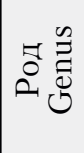 & & & 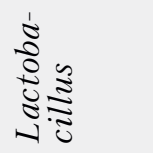 & & & & 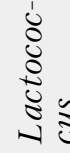 & & & & & & 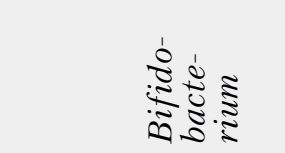 & & & \\
\hline
\end{tabular}




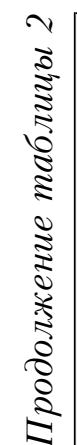

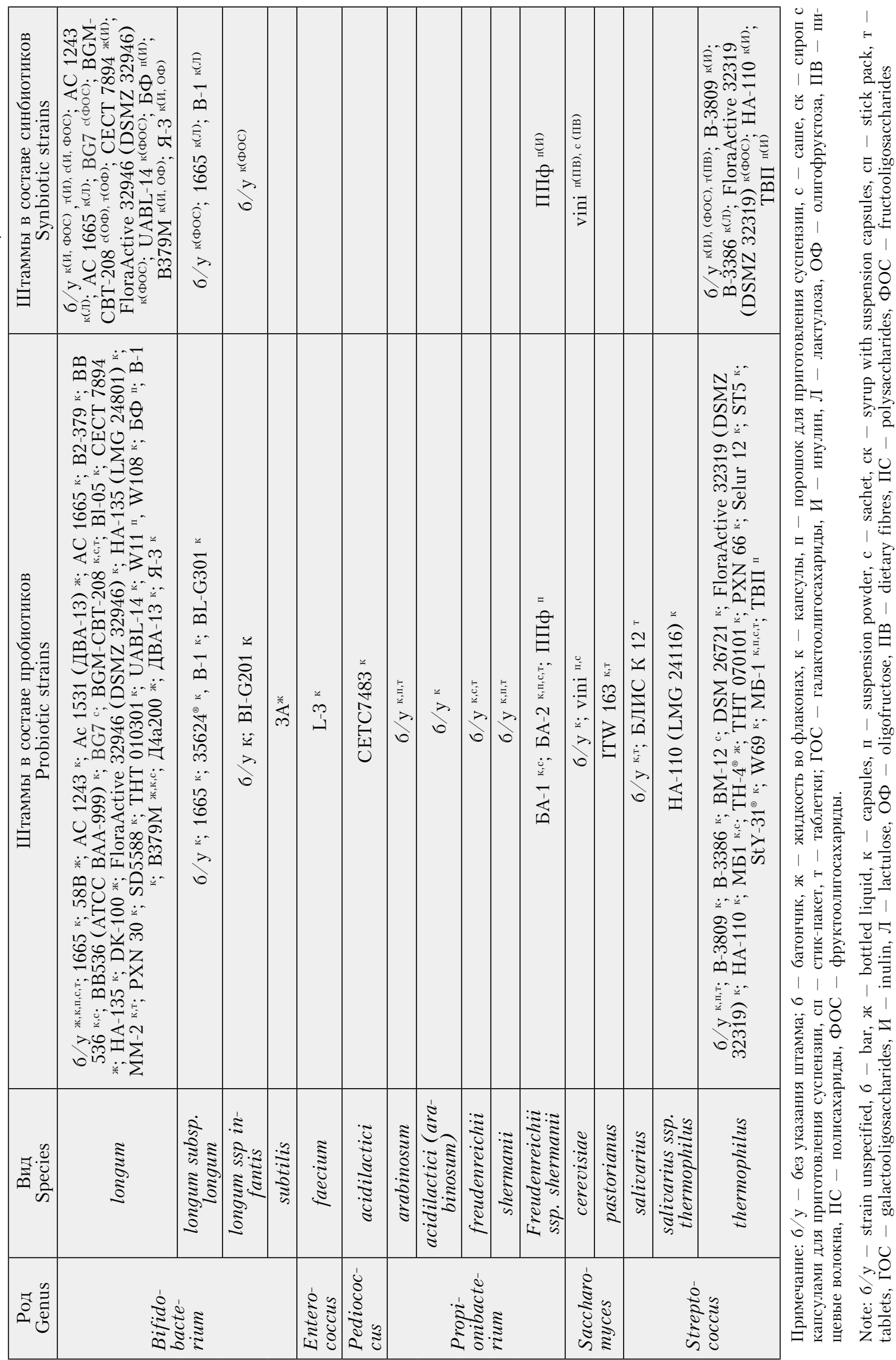




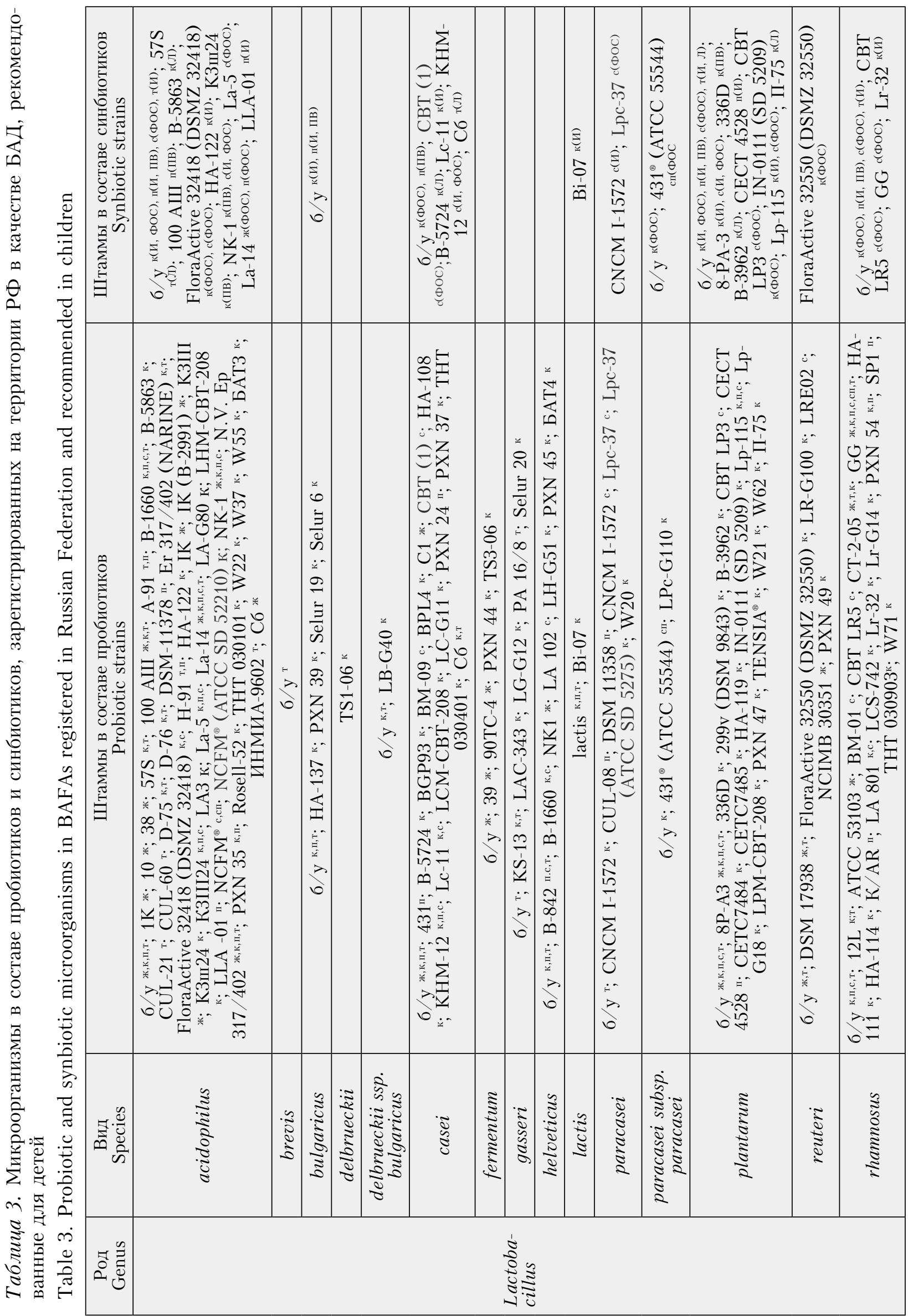




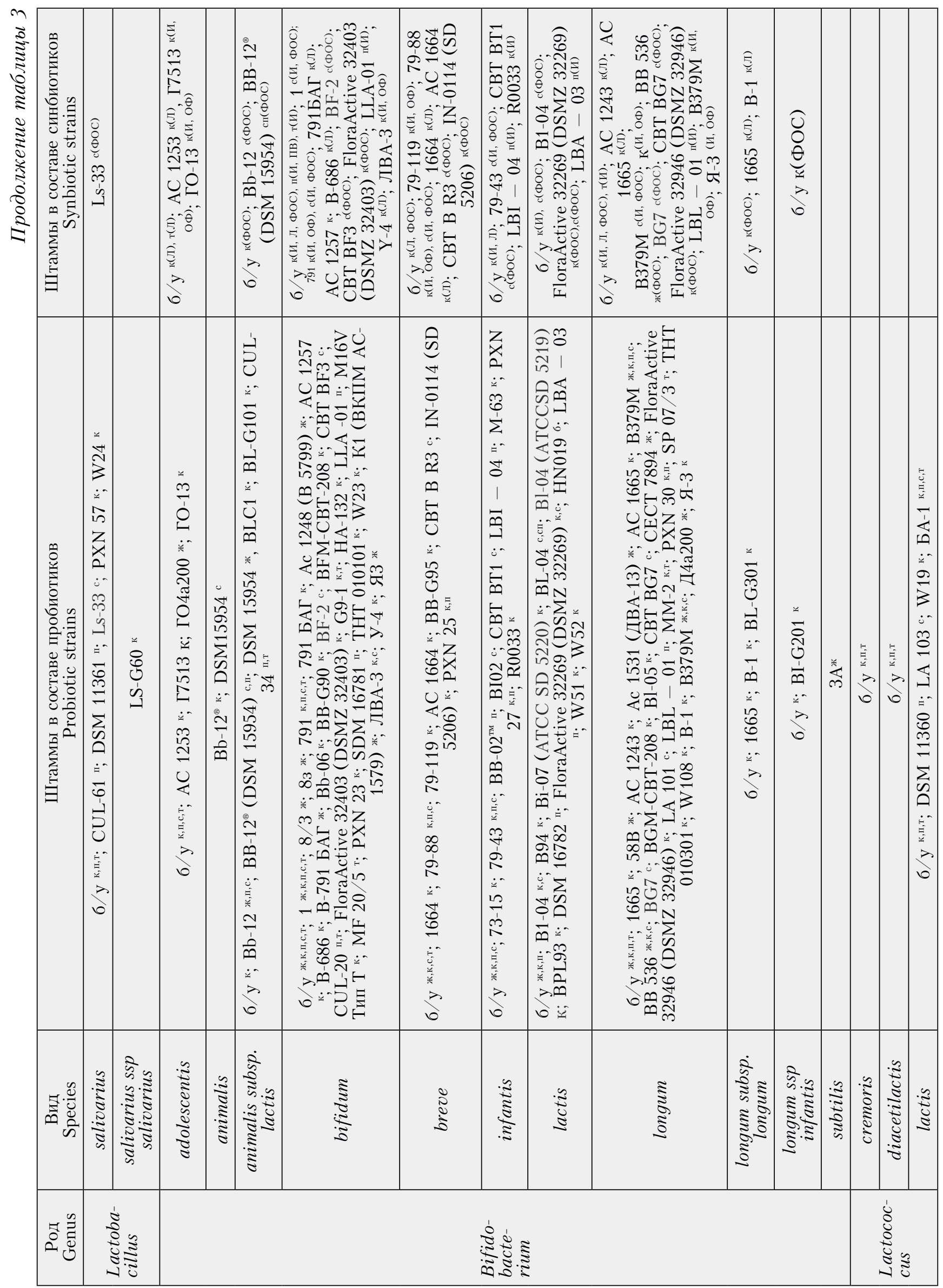




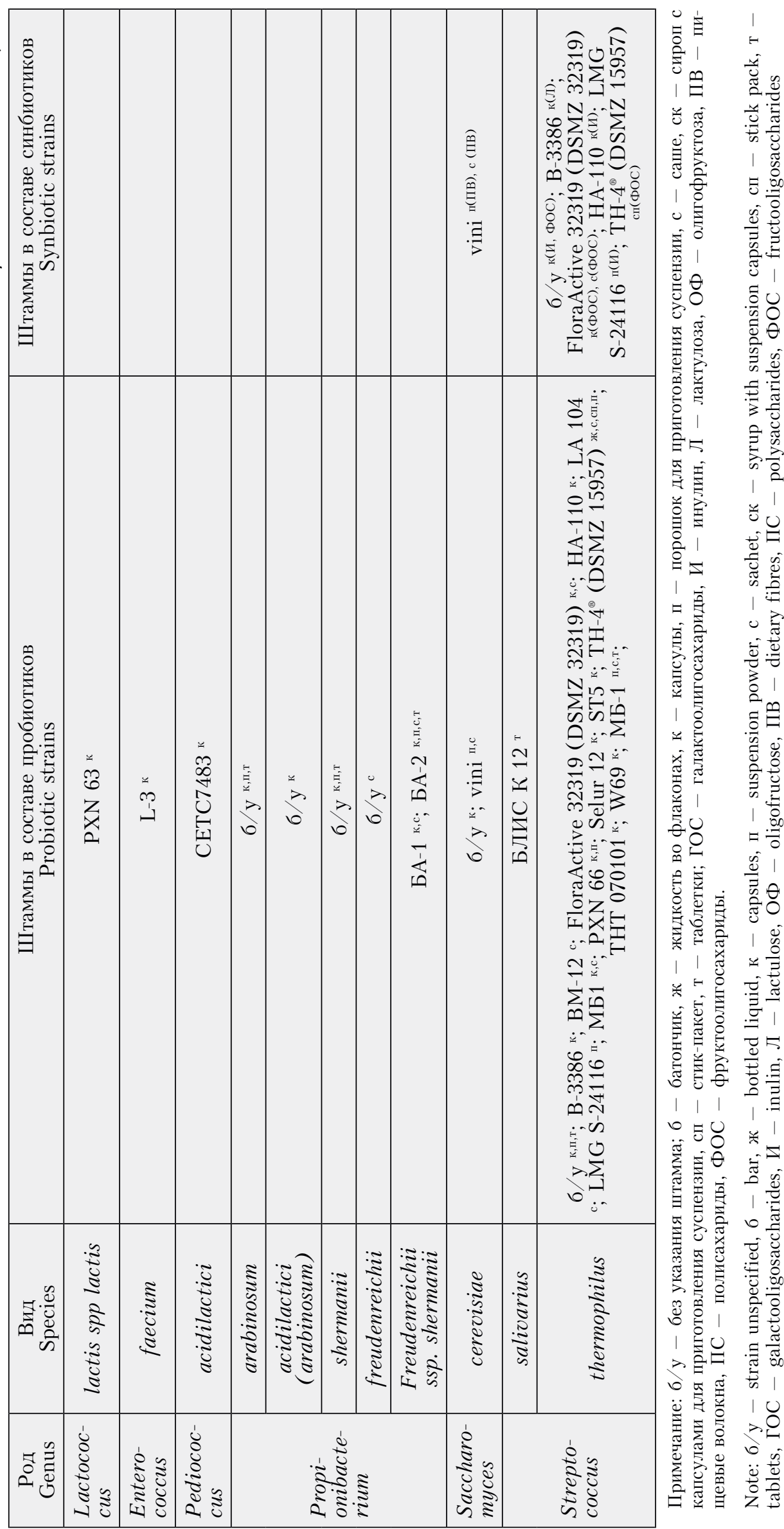


Таблица 4. Микроорганизмы в составе пробиотиков, зарегистрированных на территории РФ в качестве ЛС

Table 4. Probiotic microorganisms in drugs registered in Russian Federation

\begin{tabular}{|c|c|c|c|}
\hline $\begin{array}{l}\text { Род } \\
\text { Genus }\end{array}$ & $\begin{array}{c}\text { Вид } \\
\text { Species }\end{array}$ & $\begin{array}{c}\text { Штаммы, } \\
\text { рекомендованные взрослым } \\
\text { Strains recommended in adults }\end{array}$ & $\begin{array}{c}\text { Штаммы, рекомендованные } \\
\text { детям } \\
\text { Strains recommended in children }\end{array}$ \\
\hline \multirow{6}{*}{ Lactobacillus } & acidophilus & 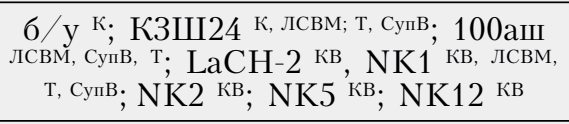 & $\begin{array}{c}\text { КЗШ24 лсвм, т; 100аш лсвм, т } ; \\
\text { NК1 лсвм, т }\end{array}$ \\
\hline & $\begin{array}{l}\text { casei rhamnosus } \\
\text { doderleini }\end{array}$ & $\sigma / y^{\kappa в}$ & - \\
\hline & doderleini & $6 / \mathrm{y}^{\mathrm{Кв}}$ & - \\
\hline & fermentum & 90Т-С4 лсвм & б/у к; 90Т-С4 лсвм \\
\hline & plantarum & б/у К, пв; 8Р-АЗ Мм, к, лсвМ, СупВ & б/y к, пв ; 8Р-АЗ лсвм \\
\hline & rhamnosus & - & GG ${ }^{\text {тж }}$ \\
\hline \multirow{3}{*}{ Bifidobacterium } & animalis & - & $\mathrm{Bb}-12$ тж \\
\hline & bifidum & $\begin{array}{c}\text { б/у К, лСвМ, ПВ,ПВМ; № } 1 \text { К, ММ, ПВ, СупРВ; } \\
1 \text { лРВМ, лСВ, ЛСВМ, СупРВ; } \\
791 \text { К, лРвм, лсвМ, СупРВ, }\end{array}$ & 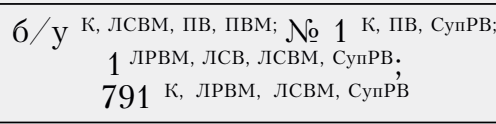 \\
\hline & longum & б/y КК & $\sigma / y^{\text {КК }}$ \\
\hline Escherichia & coli & М-17 лсв & М-17 лсв \\
\hline Enterococcus & faecium & б/y & б/y кк \\
\hline Saccharomyces & boulardii & CNCM I-745 к, псв & CNCM I-745 к, псв \\
\hline
\end{tabular}

Примечание: б/у - без указания штамма; К - капсулы, КВ - капсулы вагинальные, КК - капсулы кишечнорастворимые, ЛРВМ - лиофилизат для приготовления раствора для приема внутрь и местного применения, ЛСВ - лиофилизат для приготовления суспензии для приема внутрь, ЛСВМ - лиофилизат для приготовления суспензии для приема внутрь и местного применения, ММ - мазь для местного применения, ПВ - порошок для приема внутрь, ПВМ - порошок для приема внутрь и местного применения, ПСВ - порошок для приготовления суспензии для приема внутрь, СупВ - суппозитории вагинальные, СупРВ - суппозитории ректальные и вагинальные, Т - таблетки, ТЖ - таблетки жевательные.

Note: $\sigma / \mathrm{y}$ - strain unspecified, K - capsules, КВ - vaginal capsules, КК - enteric capsules, JPBM - soluble oral and topical use lyophilisate, ЛСВ - oral suspension lyophilisate, ЛСВM - oral suspension and topical use lyophilisate, MM topical ointment, ПВ - oral powder, ПВМ - oral and topical powder, ПСВ - oral suspension powder, CyпB - vaginal suppositories, СупРВ - rectal and vaginal suppositories, $\mathrm{T}-$ tablets, ТЖ - chewable tablets

и обогащенных ими функциональных продуктов, зарегистрированных в РФ для лечения и профилактики заболеваний гастроэнтерологического профиля, представлена в таблицах ниже.

\section{2 Лечение и профилактика заболеваний гастроэнтерологического профиля у взрослых}

\subsection{1 Лечение и профилактика диареи 4.2.1.1 Лечение острой диареи См. табл. 7.}

4.2.1.2 Профилактика антибиотикоассоциированной диареи (ААД)

См. табл. 8.

\subsubsection{3 Профилактика C. difficile-accouи- ированной болезни}

См. табл. 9.

\subsection{2 Эрадикация инфекции Н. pylori}

Назначение пробиотиков уменьшает частоту побочных эффектов антибактериальной терапии при проведении эрадикации инфекции $H$. pylori (табл. 10) [42].

\subsection{3 Лечение и профилактика воспали тельных заболеваний кичечника (ВЗК)}

В РФ не зарегистрированы пробиотические штаммы, эффективные для лечения и профилактики воспалительных заболеваний кишечника (язвенный колит, болезнь Крона, паучит) у взрослых.

\subsection{4 Синдром раздраженного кишечника (СРК)}

Пробиотики уменьшают выраженность абдоминальной боли и вздутия живота, а также увеличивают показатели уровня качества жизни у пациентов с СРК (табл. 11).

\subsection{5 Функциональный запор}

Основными эффектами пробиотиков, пребиотиков и обогащенных ими функциональных пищевых продуктов при функциональном запоре являются увеличение кратности дефекации в неделю, 
Таблица 5. Функциональные и обогащенные пробиотиками и пребиотиками пищевые продукты Table 5. Functional, probiotic- and prebiotic-enriched foods

\begin{tabular}{|c|c|c|c|}
\hline $\begin{array}{c}\text { Род } \\
\text { Genus }\end{array}$ & $\begin{array}{c}\text { Вид } \\
\text { Species }\end{array}$ & $\begin{array}{l}\text { Штамм } \\
\text { Strain }\end{array}$ & $\begin{array}{c}\text { Штаммы с пробиотиками } \\
\text { Probiotic strains }\end{array}$ \\
\hline \multirow{10}{*}{ Lactobacillus } & acidophilus & б/y й,кмп & - \\
\hline & adolescentis & MC-42 к, кмп & - \\
\hline & bulgaricus & б/y й,пп, пдп & б/y й(ФОС), пा(ПВ, Л), пдп(Л, ФОС) \\
\hline & $\begin{array}{c}\text { delbrueckii subsp. } \\
\text { Bulgaricus }\end{array}$ & $\sigma / \mathrm{y}^{\text {й }}$ & \\
\hline & fermentum & б/y пдп & - \\
\hline & paracasei & $6 / \mathrm{y}$ пдп & - \\
\hline & plantarum & Tensia DSM 21380* (сыр) & \\
\hline & $\begin{array}{l}\text { casei } s s p . \\
\text { paracasei }\end{array}$ & $\begin{array}{c}\text { б/у с ; CNCM I-1518 (DN-114 001, } \\
\text { Imunitass) кмп; F } 19 \text { с; }\end{array}$ & - \\
\hline & reuteri & $\sigma / \mathrm{y}^{\pi д п, с}$ & - \\
\hline & rhamnosus & GG й,с,пдп,пп; 2 PR пдп & - \\
\hline \multirow{5}{*}{ Bifidobacterium } & animalis & BB-12 й,с & - \\
\hline & $\begin{array}{l}\text { animalis subsp. } \\
\text { lactis }\end{array}$ & $\begin{array}{l}\text { DN-173 } 010 \text { (CNCM I-2494, } \\
\text { ActiRegularis) й, кмп } \\
\end{array}$ & - \\
\hline & bifidum & 792 к & - \\
\hline & lactis & $\begin{array}{c}\sigma / \mathrm{y}^{\text {к,кмп,пп, } ; ~ b 12 ~(N C C ~ 362 / D S M ~} \\
10140)^{\text {пп,пдп; }} \text { BB12 й,пдп,с; BL } 818 \text { пдп,пп } \\
\end{array}$ & $\begin{array}{l}\text { б/y пп(ПВ), с(ФОС, ГОС); } \\
\text { ВВ12 пдп(ФОС), с(ФОС) }\end{array}$ \\
\hline & longum & б/ $/ \mathrm{y}^{\text {к, кмп, пдп }}$ & - \\
\hline Streptococcus & thermophilus & б/y й,кмп,пा,пдп,с & 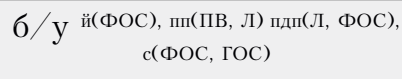 \\
\hline Enterococcus & faecium & L-3* (каша) & \\
\hline
\end{tabular}

Примечание: * - рекомендованы к употреблению только для взрослых; й - йогурт, к - кефир, кмп - кисломолочный продукт, пп - продукт прикорма (смеси, молочные продукты, каши), пдп - продукт детского питания (смеси, молочные продукты, каши и пр.), с - смесь для приготовления; ГОС - галактоолигосахариды, И - инулин, Л - лактулоза, ОФ - олигофруктоза, ПВ - пищевые волокна, ПС - полисахариды, ФОС - фруктоолигосахариды.

Note: * - recommended in adults only, й - yoghurt, к - kefir, кмп - sour milk product, пп - complementary food (formula, milk products, porridges), пдп - baby food (formula, milk products, porridges, etc.), с - formula for preparation, ГОС - galactooligosaccharides, И - inulin, Л - lactulose, ОФ - oligofructose, ПВ - dietary fibres, ПС - polysaccharides, ФОС - fructooligosaccharides

Таблица 6. Уровни доказательности Оксфордского центра медицины, основанной на доказательствах для оценки эффективности лечения применительно к вопросу «Помогло ли это лечение?»

Table 6. Oxford Centre for Evidence-Based Medicine's levels of evidence for assessing treatment efficacy by question "Did the treatment help?"

\begin{tabular}{|c|c|}
\hline $\begin{array}{c}\text { Уровень доказательности (УД) } \\
\text { Level of evidence (LOE) }\end{array}$ & $\begin{array}{l}\text { Тип исследования } \\
\text { Study type }\end{array}$ \\
\hline 1 & $\begin{array}{c}\text { Систематический обзор рандомизированных исследований } \\
\text { Systematic review of randomised trials }\end{array}$ \\
\hline 2 & $\begin{array}{l}\text { Рандомизированное или обсервационное исследование, } \\
\text { продемонстрировавшее эффективность } \\
\text { Randomised or observational study demonstrating efficacy }\end{array}$ \\
\hline 3 & $\begin{array}{c}\text { Нерандомизированное контролируемое когортное исследование } \\
\text { динамическое наблюдение } \\
\text { Non-randomised controlled cohort study/dynamic observation }\end{array}$ \\
\hline 4 & $\begin{array}{c}\text { Серии случаев, исследования «случай-контроль» } \\
\text { Case series, case-control studies }\end{array}$ \\
\hline 5 & $\begin{array}{l}\text { Обоснование механизма действия } \\
\text { Mechanism of action rationale }\end{array}$ \\
\hline
\end{tabular}


Таблица 7. Пробиотические штаммы, эффективные для лечения острой диареи у взрослых

Table 7. Probiotic strains effective in acute diarrhoea in adults

\begin{tabular}{|c|c|c|c|}
\hline $\begin{array}{c}\text { Пробиотический штамм } \\
\text { Probiotic strain }\end{array}$ & $\begin{array}{c}\text { Рекомендуемая доза } \\
\text { Recommended dose }\end{array}$ & $\begin{array}{c}\text { УД } \\
\text { LOE }\end{array}$ & $\begin{array}{c}\text { Ссылки } \\
\text { References }\end{array}$ \\
\hline Saccharomyces boulardii CNCM I-745 & $\begin{array}{c}250 \mathrm{m \Gamma} \times 2 \text { paза в день } \\
250 \mathrm{mg} \times 2 \text { times daily }\end{array}$ & 2 & $\begin{array}{c}\text { Allen S.J. et al., 2010 [32], } \\
\text { Höchter W. et al., 1990 [33] }\end{array}$ \\
\hline Lactobacillus rhamnosus GG & $\begin{array}{c}10^{9} \mathrm{KOE} \times 2 \text { paза в день } \\
10^{9} \mathrm{CFU} \times 2 \text { times daily }\end{array}$ & 3 & Grossi E. et al., 2010 [34] \\
\hline
\end{tabular}

Таблица 8. Пробиотические штаммы, эффективные для профилактики антибиотико-ассоциированной диареи у взрослых

Table 8. Probiotic strains effective in antibiotic-associated diarrhoea prevention in adults

\begin{tabular}{|c|c|c|c|c|}
\hline $\begin{array}{l}\text { Пробиотический штамм } \\
\text { Probiotic strain }\end{array}$ & $\begin{array}{l}\text { Рекомендуемая доза } \\
\text { Recommended dose }\end{array}$ & $\begin{array}{c}\text { УД } \\
\text { LOE }\end{array}$ & $\begin{array}{c}\text { Комментарий } \\
\text { Comment }\end{array}$ & $\begin{array}{l}\text { Ссылки } \\
\text { References }\end{array}$ \\
\hline $\begin{array}{l}\text { Lactobacillus } \\
\text { rhamnosus } G G\end{array}$ & $\begin{array}{l}10^{10} \mathrm{KOE} \times 2 \text { раза в день } \\
10^{10} \mathrm{CFU} \times 2 \text { times daily }\end{array}$ & 1 & \multirow{2}{*}{$\begin{array}{c}\text { Профилактика ААД у амбу- } \\
\text { латорных и госпитализиро- } \\
\text { ванных пациентов } \\
\text { AAD prevention in hospital } \\
\text { and outpatients }\end{array}$} & \multirow{2}{*}{$\begin{array}{l}\text { Hempel S. } \\
\text { et al., } 2012 \\
\text { [35] }\end{array}$} \\
\hline $\begin{array}{l}\text { Saccharomyces boulardii } \\
\text { CNCM I-745 }\end{array}$ & $\begin{array}{l}5 \times 10^{9} \mathrm{KOE} \times 2 \text { раза в день } \\
5 \times 10^{9} \mathrm{CFU} \times 2 \text { times daily }\end{array}$ & 1 & & \\
\hline $\begin{array}{l}\text { Lactobacillus acidophilus } \\
\text { NCFM, L. paracasei } \\
\text { Lpc-37, Bifidobacterium } \\
\text { lactis Bi-07, B. lactis } \\
\text { Bl-04 }\end{array}$ & $\begin{array}{l}1.7^{10} \mathrm{KOE} \mathrm{в} \mathrm{день} \\
1.7^{10} \mathrm{CFU} \text { daily }\end{array}$ & 2 & $\begin{array}{c}\text { Профилактика ААД } \\
\text { у госпитализированных } \\
\text { пациентов } \\
\text { AAD prevention in hospital }\end{array}$ & $\begin{array}{l}\text { Ouwe- } \\
\text { hand A.C. } \\
\text { et al., } 2014 \\
{[36]}\end{array}$ \\
\hline $\begin{array}{l}\text { Lactobacillus acidophilus } \\
\text { LA5, Bifidumbacterium } \\
\text { animalis ssp. Lactis BB- } \\
12\end{array}$ & $\begin{array}{c}2 \times 10^{9} \mathrm{KOE} \times 2 \text { раза } \\
\text { в день } \\
2 \times 10^{9} \text { CFU } \times 2 \text { times daily }\end{array}$ & 2 & $\begin{array}{c}\text { Сокращение длительности и } \\
\text { уменьшение тяжести диареи } \\
\text { на фоне приема амоксицил- } \\
\text { лина или цефадроксила } \\
\text { Reduced diarrhoea duration } \\
\text { and severity with amoxicillin } \\
\text { or cefadroxil }\end{array}$ & $\begin{array}{l}\text { Chatter- } \\
\text { jee S. et al. } \\
2013 \text { [37] }\end{array}$ \\
\hline $\begin{array}{l}\text { Lactobacillus casei DN- } \\
114001 \text { (Imunitass) }\end{array}$ & 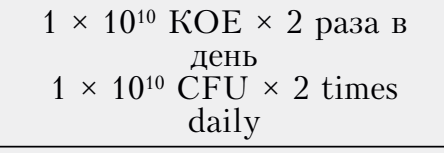 & 2 & $\begin{array}{c}\text { Профилактика ААД } \\
\text { у госпитализированных } \\
\text { пациентов } \\
\text { AAD prevention in hospital }\end{array}$ & $\begin{array}{l}\text { Hickson M. } \\
\text { et al., 2007 } \\
{[38]}\end{array}$ \\
\hline $\begin{array}{l}\text { Lactobacillus reuteri } \\
\text { DSM } 17938\end{array}$ & $\begin{array}{c}1 \times 10^{8} \mathrm{KOE} \times 2 \text { раза в } \\
\text { день } \\
1 \times 10^{8} \mathrm{CFU} \times 2 \text { times daily }\end{array}$ & 3 & $\begin{array}{c}\text { Профилактика ААД } \\
\text { у госпитализированных } \\
\text { пациентов } \\
\text { AAD prevention in hospital }\end{array}$ & $\begin{array}{l}\text { Cimper- } \\
\text { man L. } \\
\text { et al., 2011 } \\
\text { [39] }\end{array}$ \\
\hline
\end{tabular}

Таблища 9. Пробиотические штаммы и пребиотики, эффективные для профилактики C.difficileассоциированной болезни у взрослых

Table 9. Probiotic strains and prebiotics effective in $C$. difficile-associated disease prevention in adults

\begin{tabular}{|c|c|c|c|}
\hline $\begin{array}{c}\text { Пробиотический штамм, пребиотик } \\
\text { Probiotic strain, prebiotic }\end{array}$ & $\begin{array}{l}\text { Рекомендуемая доза } \\
\text { Recommended dose }\end{array}$ & $\begin{array}{c}\text { УД } \\
\mathrm{LOE}\end{array}$ & $\begin{array}{c}\text { Ссылки } \\
\text { References }\end{array}$ \\
\hline Saccharomyces boulardii CNCM I-745 & $\begin{array}{l}5 \times 10^{9} \mathrm{KOE} \times 2 \text { раза в день } \\
5 \times 10^{9} \mathrm{CFU} \times 2 \text { times daily }\end{array}$ & 3 & $\begin{array}{l}\text { Goldenberg J.Z. et al., } \\
2013 \text { [40] }\end{array}$ \\
\hline $\begin{array}{l}\text { Олигофруктоза } \\
\text { Oligofructose }\end{array}$ & $\begin{array}{l}4 \text { г } \times 3 \text { раза в день } \\
4 \mathrm{~g} \times 3 \text { times daily }\end{array}$ & 3 & Lewis S. et al., 2005 [41] \\
\hline
\end{tabular}

улучшение консистенции стула и облегчение дефекации (табл. 12).

4.2.6 Функциональные нарушения гастроэнтерологического профиля у здоровых взрослых

См. табл. 13.

\subsection{7 Печеночная энцефалопатия}

См. табл. 14.

4.3 Лечение и профилактика заболеваний гастроэнтерологического профиля у детей

4.3.1 Лечение острого гастроэнтерита См. табл. 15. 
Таблища 10. Пробиотические штаммы, рекомендованные при эрадикационной терапии инфекции H. pylori у взрослых

Table 10. Probiotic strains recommended in H. pylori eradication therapy in adults

\begin{tabular}{|c|c|c|c|c|}
\hline $\begin{array}{l}\text { Пробиотический штамм } \\
\text { Probiotic strain }\end{array}$ & $\begin{array}{l}\text { Рекомендуемая доза } \\
\text { Recommended dose }\end{array}$ & $\begin{array}{l}\text { УД } \\
\text { LOE }\end{array}$ & $\begin{array}{l}\text { Комментарий } \\
\text { Comment }\end{array}$ & $\begin{array}{l}\text { Ссылки } \\
\text { References }\end{array}$ \\
\hline $\begin{array}{l}\text { Saccharomyces boulardii } \\
\text { CNCM I-745 }\end{array}$ & $\begin{aligned} 5 \times 10^{9} \mathrm{KOE} & \times 2 \text { раза в день } \\
5 & \times 10^{9} \mathrm{CFU} \times 2 \text { times daily }\end{aligned}$ & 1 & - & $\begin{array}{c}\text { Golden- } \\
\text { berg J.Z. et } \\
\text { al., } 2013 \text { [40] }\end{array}$ \\
\hline $\begin{array}{l}\text { Lactobacillus reuteri } \\
\text { DSM } 17938\end{array}$ & $\begin{array}{c}1 \times 10^{8} \mathrm{KOE} \times 3 \text { раза в день } \\
1 \times 10^{8} \mathrm{CFU} \times 3 \text { times daily }\end{array}$ & 2 & $\begin{array}{c}\text { При эрадикационной } \\
\text { терапии препаратами } \\
\text { второй линии } \\
\text { с применением } \\
\text { левофлоксацина } \\
\text { In second line-drug } \\
\text { eradication therapy } \\
\text { with levofloxacin }\end{array}$ & $\begin{array}{l}\text { Shi X. et al., } \\
2019 \text { [42] }\end{array}$ \\
\hline $\begin{array}{l}\text { Lactobacillus rhamnosus } \\
\text { GG }\end{array}$ & $\begin{array}{c}6 \times 10^{9} \mathrm{KOE} \times 2 \text { раза в день; } \\
1 \times\left(10^{8}-10^{9}\right) \mathrm{KOE} \times 2 \text { раза в день } \\
6 \times 10^{9} \mathrm{CFU} \times 2 \text { times daily; } \\
1 \times\left(10^{8}-10^{9}\right) \mathrm{CFU} \times 2 \text { times daily }\end{array}$ & 2 & $\begin{array}{l}\text { При эрадикационной } \\
\text { терапии препаратами } \\
\text { первой линии } \\
\text { In first line-drug } \\
\text { eradication therapy }\end{array}$ & $\begin{array}{l}\text { Dang Y. et } \\
\text { al., 2014 [43], } \\
\text { Ojetti V. et } \\
\text { al., } 2012 \text { [44] }\end{array}$ \\
\hline $\begin{array}{l}\text { Bifidobacterium bifidum } \\
\text { W23, B. lactis W51, } \\
\text { Lactobacillus acidophilus } \\
\text { W37, L. acidophilus } \\
\text { W55, L. paracasei W20, } \\
\text { L. plantarum W62, } \\
\text { L. rhamnosus W71, } \\
\text { L. salivarius W24 }\end{array}$ & $\begin{array}{l}1 \times 10^{9} \mathrm{KOE} \times 2 \text { раза в день } \\
1 \times 10^{9} \mathrm{CFU} \times 2 \text { times daily }\end{array}$ & 4 & $\begin{array}{l}\text { При эрадикационной } \\
\text { терапии препаратами } \\
\text { первой линии } \\
\text { In first line-drug } \\
\text { eradication therapy }\end{array}$ & $\begin{array}{c}\text { Ли И.А. } \\
\text { и соавт., } 2013 \\
\text { [45] }\end{array}$ \\
\hline
\end{tabular}

Таблица 11. Пробиотические штаммы, эффективные при СРК у взрослых

Table 11. Probiotic strains effective in IBS in adults

\begin{tabular}{|c|c|c|c|c|}
\hline $\begin{array}{l}\text { Пробиотический штамм } \\
\text { Probiotic strain }\end{array}$ & $\begin{array}{c}\text { Рекомендуемая доза } \\
\text { Recommended dose }\end{array}$ & $\begin{array}{l}\text { УД } \\
\text { LOE }\end{array}$ & $\begin{array}{l}\text { Комментарий } \\
\text { Comment }\end{array}$ & $\begin{array}{l}\text { Ссылки } \\
\text { References }\end{array}$ \\
\hline $\begin{array}{l}\text { Lactobacillus } \\
\text { plantarum 299v (DSM } \\
9843 \text { ) }\end{array}$ & $\begin{array}{c}1 \times 10^{10} \mathrm{KOE} \times \\
1 \text { pas в день } \\
1 \times 10^{10} \mathrm{CFU} \times \\
1 \text { time daily } \\
\end{array}$ & 2 & $\begin{array}{c}\text { Уменьшение выраженности } \\
\text { боли в животе } \\
\text { Relieved abdominal pain }\end{array}$ & $\begin{array}{c}\text { Ducrotté P. et } \\
\text { al., 2012 [46], } \\
\text { Ford A.C. et al., } \\
\text { 2014 [47] }\end{array}$ \\
\hline $\begin{array}{l}\text { Saccharomyces } \\
\text { boulardii CNCM I-745 }\end{array}$ & $\begin{array}{l}5 \times 10^{9} \text { КОЕ } \times \\
2 \text { раза в день } \\
5 \times 10^{9} \mathrm{CFU} \times \\
2 \text { times daily }\end{array}$ & 2 & $\begin{array}{c}\text { Улучшение качества жизни } \\
\text { пациентов с CPК } \\
\text { Improved quality of life in IBS }\end{array}$ & $\begin{array}{l}\text { Choi C.H. et al., } \\
2011[48]\end{array}$ \\
\hline $\begin{array}{l}\text { Bifidobacterium } \\
\text { longum ( } \text { infantis) } \\
35624\end{array}$ & $\begin{array}{l}5 \times 10^{9} \mathrm{KOE} \times \\
2 \text { раза в день } \\
5 \times 10^{9} \mathrm{CFU} \times \\
2 \text { times daily }\end{array}$ & 2 & $\begin{array}{l}\text { Субъективное уменьшение } \\
\text { общих симптомов СРК } \\
\text { Subjective improvement of } \\
\text { general of IBS symptoms }\end{array}$ & $\begin{array}{c}\text { Whorwell P.J. } \\
\text { et al., } 2006 \text { [49], } \\
\text { Moayyedi P. et al., } \\
2010 \text { [50] }\end{array}$ \\
\hline $\begin{array}{l}\text { Lactobacillus } \\
\text { plantarum CECT7484, } \\
\text { Lactobacillus } \\
\text { plantarum CECT7485, } \\
\text { Pediococcus acidilactici } \\
\text { CECT7483 }\end{array}$ & $\begin{array}{c}(1-2) \times 10^{9} \mathrm{KOE} \\
\text { в день (каждого } \\
\text { штамма) } \\
(1-2) \times 10^{9} \mathrm{CFU} \\
\text { daily (each strain) }\end{array}$ & 2 & $\begin{array}{l}\text { Улучшение качества жизни } \\
\text { пациентов с CPK (опросник } \\
\text { IBS-QoL) } \\
\text { Improved quality of life in IBS } \\
\text { (IBS-QoL questionnaire) }\end{array}$ & $\begin{array}{l}\text { Lorenzo-Zúñiga V. } \\
\text { et al., } 2014 \text { [51] }\end{array}$ \\
\hline $\begin{array}{l}\text { Bifidobacterium } \\
\text { bifidum, B. } \\
\text { longum, B. infantis, } \\
\text { Lactobacillus } \\
\text { rhamnosus } \\
\text { (Флорасан-D) }\end{array}$ & $\begin{array}{c}1 \text { капсула }(250 \text { мг }) \\
\times 2 \text { раза в день } \\
1 \text { capsule }(250 \mathrm{mg}) \times \\
2 \text { times daily }\end{array}$ & 2 & $\begin{array}{c}\text { Уменьшение клинических } \\
\text { симптомов и устранение } \\
\text { синдрома избыточного } \\
\text { бактериального роста у } \\
\text { пациентов с CPК с запором } \\
\text { Improved clinical symptoms } \\
\text { and eliminated bacterial } \\
\text { overgrowth in IBS with } \\
\text { constipation } \\
\end{array}$ & $\begin{array}{l}\text { Ivashkin V. et al., } \\
2015 \text { [52] }\end{array}$ \\
\hline
\end{tabular}


Продолжение таблицы 11

\begin{tabular}{|c|c|c|c|c|}
\hline $\begin{array}{c}\text { Пробиотический штамм } \\
\text { Probiotic strain }\end{array}$ & $\begin{array}{c}\text { Рекомендуемая доза } \\
\text { Recommended dose }\end{array}$ & $\begin{array}{l}\text { УД } \\
\mathrm{LOE}\end{array}$ & $\begin{array}{l}\text { Комментарий } \\
\text { Comment }\end{array}$ & $\begin{array}{c}\text { Ссылки } \\
\text { References }\end{array}$ \\
\hline $\begin{array}{l}\text { Bifidobacterium } \\
\text { animalis subsp. lactis } \\
\text { DN-173 010 (CNCM } \\
\text { I-2494, ActiRegularis) }\end{array}$ & $\begin{array}{l}1,25 \times 10^{10} \mathrm{KOE} \times \\
2 \text { раза в день } \\
1.25 \times 10^{10} \mathrm{CFU} \times \\
2 \text { times daily }\end{array}$ & 2 & $\begin{array}{l}\text { Улучшение качества жизни } \\
\text { (опросник Health-Related } \\
\text { Quality of Life), уменьшение } \\
\text { выраженности вздутия } \\
\text { живота и нормализация } \\
\text { частоты стула у пациентов с } \\
\text { СРК с запором после } \\
\text { Improved quality of life } \\
\text { ( "Health-Related Quality of } \\
\text { Life” questionnaire), reduced } \\
\text { abdominal bloating and } \\
\text { normalised stool frequency in } \\
\text { IBS with constipation }\end{array}$ & $\begin{array}{c}\text { Guyonnet D. et al., } \\
2009 \text { [53] }\end{array}$ \\
\hline $\begin{array}{l}\text { Lactobacillus } \\
\text { animalis lactis } \\
\text { BB12, Lactobacillus } \\
\text { acidophilus LA- } \\
\text { 5, Lactobacillus } \\
\text { delbrueckii nodвuд } \\
\text { bulgaricus LBY- } \\
\text { 27, Streptococcus } \\
\text { thermophilus STY-31 }\end{array}$ & $\begin{array}{l}4 \times 10^{9} \mathrm{KOE} \times \\
2 \text { раза в день } \\
4 \times 10^{9} \mathrm{CFU} \times \\
2 \text { times daily }\end{array}$ & 3 & $\begin{array}{c}\text { Уменьшение выраженности } \\
\text { абдоминальной боли и } \\
\text { метеоризма } \\
\text { Relieved abdominal pain and } \\
\text { flatulence }\end{array}$ & $\begin{array}{l}\text { Jafari E. et al., } \\
2014[54]\end{array}$ \\
\hline
\end{tabular}

Таблица 12. Пробиотические штаммы и пребиотики, эффективные при функциональном запоре у взрослых

Table 12. Probiotic strains and prebiotics effective in functional constipation in adults

\begin{tabular}{|c|c|c|c|c|}
\hline $\begin{array}{c}\text { Пробиотический штамм, } \\
\text { пребиотик }\end{array}$ & Рекомендуемая доза & Уд & Комментарий & Ссылки \\
\hline $\begin{array}{l}\text { Bifidobacterium animalis } \\
\text { subsp. lactis DN-173 } \\
\text { o10 (CNCM I-2494, } \\
\text { ActiRegularis) }\end{array}$ & $\begin{array}{c}1,25 \times 10^{10} \mathrm{KOE} \times 1 \text { раз } \\
\text { в день } \\
1.25 \times 10^{10} \mathrm{CFU} \times 1 \text { time } \\
\text { daily }\end{array}$ & 2 & $\begin{array}{c}\text { Эффективность } \\
\text { продемонстрирована } \\
\text { у женщин } \\
\text { Efficacy proved in women }\end{array}$ & $\begin{array}{l}\text { Yang, Y.X. et } \\
\text { al., 2008 [55] }\end{array}$ \\
\hline $\begin{array}{l}\text { Lactobacillus reuteri } \\
\text { DSM } 17938\end{array}$ & $\begin{array}{c}1 \times 10^{8} \text { КОЕ } \times 2 \text { раза } \\
\text { в день } \\
1 \times 10^{8} \text { CFU } \times 2 \text { times daily }\end{array}$ & 3 & & $\begin{array}{l}\text { Ojetti V. et al., } \\
2014 \text { [56] }\end{array}$ \\
\hline Лактулоза & $\begin{array}{c}20-40 \text { г в день } \\
20-40 \text { g daily } \\
\end{array}$ & 2 & & $\begin{array}{c}\text { Schumann C., } \\
2002[57]\end{array}$ \\
\hline Олигофруктоза & $\begin{array}{l}20 \text { г в день } \\
20 \text { g daily }\end{array}$ & 3 & & $\begin{array}{l}\text { Nyman M., } \\
2002[58]\end{array}$ \\
\hline
\end{tabular}

Таблица 13. Пробиотики, рекомендованные при функциональных нарушениях гастроэнтерологического профиля у здоровых взрослых

Table 13. Probiotics recommended in functional gastroenterological disorders in healthy adults

\begin{tabular}{|c|c|c|c|}
\hline ФПП & $\begin{array}{c}\text { Рекомендуемая доза } \\
\text { Recommended dose }\end{array}$ & $\begin{array}{c}\text { УД } \\
\text { LOE }\end{array}$ & $\begin{array}{c}\text { Ссылки } \\
\text { References }\end{array}$ \\
\hline $\begin{array}{c}\text { Bifidobacterium animalis subsp. lactis DN- } \\
\text { 173 010 (CNCM I-2494, ActiRegularis) }\end{array}$ & $\begin{array}{c}1,25 \times 10^{10} \mathrm{KOE} \times(1-2) \text { paза в день } \\
1.25 \times 10^{10} \mathrm{CFU} \times(1-2) \text { times daily }\end{array}$ & 1 & $\begin{array}{c}\text { Eales J. et al., } \\
2016 \text { [59] }\end{array}$ \\
\hline
\end{tabular}

Таблица 14. Пребиотики, рекомендованные для пациентов с печеночной энцефалопатией у взрослых Table 14. Prebiotics recommended in hepatic encephalopathy in adults

\begin{tabular}{|l|c|c|c|}
\hline \multicolumn{1}{|c|}{ Пребиотик } & $\begin{array}{c}\text { Рекомендуемая доза } \\
\text { Recommended dose }\end{array}$ & $\begin{array}{c}\text { УД } \\
\text { LOE }\end{array}$ & $\begin{array}{c}\text { Ссылки } \\
\text { References }\end{array}$ \\
\hline $\begin{array}{l}\text { Лактулоза } \\
\text { Lactulose }\end{array}$ & $\begin{array}{c}45-90 \text { г в день } \\
45-90 \mathrm{~g} \text { daily }\end{array}$ & 1 & Gluud L.L. et al., 2016 [60] \\
\hline
\end{tabular}


Таблица 15. Пробиотические штаммы, эффективные для лечения острого гастроэнтерита у детей Table 15. Probiotic strains effective in acute gastroenteritis in children

\begin{tabular}{|l|c|c|c|}
\hline \multicolumn{1}{|c|}{$\begin{array}{c}\text { Пробиотический штамм } \\
\text { Probiotic strain }\end{array}$} & $\begin{array}{c}\text { Рекомендуемая доза } \\
\text { Recommended dose }\end{array}$ & $\begin{array}{c}\text { УД } \\
\text { LOE }\end{array}$ & $\begin{array}{c}\text { Ссылки } \\
\text { References }\end{array}$ \\
\hline Lactobacillus rhamnosus GG & $\begin{array}{c}\geq 10^{10} \text { KOE в день } \\
\geq 10^{10} \text { CFU daily }\end{array}$ & 1 & $\begin{array}{c}\text { Szajewska H, 2014 [61], } \\
\text { Szajewska H, 2013 [62] }\end{array}$ \\
\hline Lactobacillus reuteri DSM 17938 & $\begin{array}{c}10^{9} \mathrm{KOE} \times 1 \text { раз в день } \\
10^{9} \mathrm{CFU} \times 1 \text { time daily }\end{array}$ & 1 & Szajewska H. et al., 2014 [61] \\
\hline Saccharomyces boulardii CNCM I-745 & $\begin{array}{c}250-750 \text { мг в день } \\
250-750 \mathrm{mg} \text { daily }\end{array}$ & 1 & $\begin{array}{c}\text { Szajewska H. et al., 2014 [61], } \\
\text { Szajewska H. et al., 2009 [63] }\end{array}$ \\
\hline
\end{tabular}

Таблища 16. Пробиотические штаммы, эффективные для профилактики антибиотико-ассоциированной диареи у детей

Table 16. Probiotic strains effective in antibiotic-associated diarrhoea prevention in children

\begin{tabular}{|c|c|c|c|}
\hline $\begin{array}{c}\text { Пробиотический штамм } \\
\text { Probiotic strain }\end{array}$ & $\begin{array}{c}\text { Рекомендуемая доза } \\
\text { Reсоmmended dose }\end{array}$ & $\begin{array}{c}\text { Уд } \\
\text { LOE }\end{array}$ & $\begin{array}{c}\text { Ссылки } \\
\text { References }\end{array}$ \\
\hline Lactobacillus rhamnosus GG & $\begin{array}{c}(1-2) \times 10^{10} \text { KOE в день } \\
(1-2) \times 10^{10} \text { CFU daily }\end{array}$ & 1 & Szajewska H. et al., 2015 [64] \\
\hline Saccharomyces boulardii CNCM I-745 & $\begin{array}{c}250-500 \mathrm{Mr} \text { в день } \\
250-500 \mathrm{mg} \text { daily }\end{array}$ & 1 & Szajewska H. et al., 2009 [63] \\
\hline
\end{tabular}

Таблица 17. Пробиотические штаммы, эффективные для профилактики диареи у здоровых детей Table 17. Probiotic strains effective in diarrhoea prevention in healthy children

\begin{tabular}{|l|c|c|c|}
\hline $\begin{array}{l}\text { Пробиотический штамм } \\
\text { Probiotic strain }\end{array}$ & $\begin{array}{c}\text { Рекомендуемая доза } \\
\text { Recommended dose }\end{array}$ & $\begin{array}{c}\text { УД } \\
\text { LOE }\end{array}$ & $\begin{array}{c}\text { Ссылки } \\
\text { References }\end{array}$ \\
\hline $\begin{array}{l}\text { Lactobacillus casei } \\
\text { DN-114001 (Imunitass) }\end{array}$ & $\begin{array}{c}1 \times 10^{10} \mathrm{KOE} \times 2 \text { раза в день } \\
1 \times 10^{10} \mathrm{CFU} \times 2 \text { times daily }\end{array}$ & 2 & Pedone C.A. et al., 2015 [65] \\
\hline $\begin{array}{l}\text { Lactobacillus reuteri } \\
\text { DSM 17938 }\end{array}$ & $\begin{array}{c}1 \times 10^{8} \mathrm{KOE} \text { в день } \\
\text { (на протяжении 3 месяцев) } \\
10^{8} \text { CFU daily (over 3 months) }\end{array}$ & 2 & $\begin{array}{c}\text { Agustina R. et all., 2012 [66], Gutierrez- } \\
\text { Castrellon P. et all., 2014 [67] }\end{array}$ \\
\hline
\end{tabular}

Таблица 18. Пробиотические штаммы, рекомендованные при эрадикации инфекции H. pylori у детей

Table 18. Probiotic strains recommended in H. pylori eradication in children

\begin{tabular}{|c|c|c|c|c|}
\hline $\begin{array}{c}\text { Пробиотический штамм } \\
\text { Probiotic strain }\end{array}$ & $\begin{array}{l}\text { Рекомендуемая доза } \\
\text { Recommended dose }\end{array}$ & $\begin{array}{c}\text { Уд } \\
\text { LOE }\end{array}$ & $\begin{array}{c}\text { Комментарий } \\
\text { Comment }\end{array}$ & $\begin{array}{c}\text { Ссылки } \\
\text { References } \\
\end{array}$ \\
\hline $\begin{array}{l}\text { Saccharomyces boulardii } \\
\text { CNCM I-745 }\end{array}$ & $\begin{array}{l}500 \text { мг в день } \\
500 \mathrm{mg} \text { daily }\end{array}$ & 2 & $\begin{array}{c}\text { Уменьшение риска побочных } \\
\text { эффектов и повышение } \\
\text { скорости эрадикации } \\
\text { Reduced risk of side effects and } \\
\text { improved eradication rate }\end{array}$ & $\begin{array}{l}\text { Szajewska H. et } \\
\text { al., } 2015[68]\end{array}$ \\
\hline $\begin{array}{l}\text { Lactobacillus casei DN- } \\
114001 \text { (Imunitass) }\end{array}$ & $\begin{array}{l}1 \times 10^{10} \mathrm{KOE} \times \\
1 \text { pa3 в день } \\
1 \times 10^{10} \mathrm{CFU} \times \\
1 \text { time daily }\end{array}$ & 2 & $\begin{array}{c}\text { Повышение качества } \\
\text { эрадикационной терапии } \\
\text { препаратами 1-й линии } \\
\text { Improved eradication efficacy in } \\
\text { first-line therapy }\end{array}$ & $\begin{array}{l}\text { Sykora J. et al., } \\
2005 \text { [69] }\end{array}$ \\
\hline
\end{tabular}

\subsection{2 Профилактика диареи}

4.3.2.1 Профилактика антибиотико-ассочиированной диареи

См. табл. 16.

\subsubsection{2 Профилактика развития диареи См. табл. 17.}

\subsection{3 Эрадикация инфекции Н. pylori} См. табл. 18.

\author{
4.3.4 Профилактика функциональной абдоми- \\ нальной боли \\ См. табл. 19.
}


Таблища 19. Пробиотические штаммы, эффективные для профилактика функциональной абдоминальной боли у детей

Table 19. Probiotic strains effective in functional abdominal pain prevention in children

\begin{tabular}{|l|c|c|c|c|}
\hline $\begin{array}{c}\text { Пробиотический штамм } \\
\text { Probiotic strain }\end{array}$ & $\begin{array}{c}\text { Рекомендуемая доза } \\
\text { Recommended dose }\end{array}$ & $\begin{array}{c}\text { УД } \\
\text { LOE }\end{array}$ & $\begin{array}{c}\text { Комментарий } \\
\text { Соmmеnt }\end{array}$ & $\begin{array}{c}\text { Ссылки } \\
\text { References }\end{array}$ \\
\hline $\begin{array}{l}\text { Lactobacillus reuteri } \\
\text { DSM 17938 }\end{array}$ & $\begin{array}{c}10^{8} \mathrm{KOE} \mathrm{в} \mathrm{день} \\
10^{8} \mathrm{CFU} \text { daily }\end{array}$ & 1 & $\begin{array}{c}\text { При колике } \\
\text { у новорожденных } \\
\text { Inewborn infantile colic }\end{array}$ & $\begin{array}{c}\text { Urbańska M. } \\
\text { et al., 2014 } \\
\text { [70] }\end{array}$ \\
\hline $\begin{array}{l}\text { Lactobacillus } \\
\text { rhamnosus GG }\end{array}$ & $\begin{array}{c}10^{10}-10^{11} \mathrm{KOE} \times 2 \text { раза в день } \\
10^{10}-10^{11} \mathrm{CFU} \times 2 \text { times daily }\end{array}$ & 1 & - & $\begin{array}{c}\text { Horvath A. et } \\
\text { al., 2011 [71] }\end{array}$ \\
\hline
\end{tabular}

\section{Заключение}

Согласно данным проведенных исследований изменения в составе кишечной микробиоты оказывают влияние на формирование симптомов заболеваний сердечно-сосудистой, бронхолегочной, мочевыделительной, репродуктивной систем, а также желудочно-кишечного тракта и эмоциональной сферы.

Для профилактики и увеличения эффективности лечения пациентов, страдающих заболеваниями

\section{Литература / References}

1. World Gastroenterology Organisation. Probiotics and prebiotics. 2017. https://www.worldgastroenterology.org/ guidelines

2. Markowiak P., Śliżewska K. Effects of Probiotics, Prebiotics, and Synbiotics on Human Health. Nutrients. 2017;9(9):1021. DOI: 10.3390/nu9091021

3. Davani-Davari D., Negahdaripour M., Karimzadeh M., Seifan M., Mohkam M., Masoumi S. J., et al. Prebiotics: Definition, Types, Sources, Mechanisms, and Clinical Applications. Foods. 2019;8(3):92. DOI: 10.3390/ foods 8030092

4. Pandey K.R., Naik S.R., Vakil B.V. Probiotics, prebiotics and synbiotics - a review. J Food Sci Technol. 2015;52(12):7577-87. DOI: 10.1007/s13197-015-1921-1

5. Plaza-Diaz J., Ruiz-Ojeda F.J., Gil-Campos M., Gil A. Mechanisms of Action of Probiotics. Adv Nutr. 2019;10(Suppl 1):S49-66. DOI: 10.1093/advances/nmy063

6. Halloran K., Underwood M.A. Probiotic mechanisms of action. Early Hum Dev. 2019;135:58-65. DOI: 10.1016/j. earlhumdev.2019.05.010

7. Canfora E.E., Jocken J.W., Blaak E.E. Short-chain fatty acids in control of body weight and insulin sensitivity. Nat Rev Endocrinol. 2015;11(10):577-91. DOI: 10.1038 nrendo.2015.128

8. Strandwitza $P$. Neurotransmitter modulation by the gut microbiota. Brain Res. 2018;1693(Pt B):128-33. DOI: $10.1016 / \mathrm{j}$.brainres.2018.03.015

9. de Moreno de LeBlanc A., Levit R., de Giori G.S., LeB lanc J.G. Vitamin Producing Lactic Acid Bacteria as Complementary Treatments for Intestinal Inflammation. Antiinflamm Antiallergy Agents Med Chem. 2018;17(1):50-6. DOI: $10.2174 / 1871523017666180502170659$

10. Halloran K., Underwood M.A. Probiotic mechanisms of action. Early Hum Dev. 2019;135:58-65. DOI: 10.1016/j. earlhumdev.2019.05.010.

11. Scott K.P., Gratz S.W., Sheridan P.O., Flint H.J., Duncan S.H. The influence of diet on the gut microbiota. Pharmacol. Res. 2013;69:52-60. DOI: 10.1016/j. phrs.2012.10.020

12. Ze X., Duncan S.H., Louis P., Flint H.J. Ruminococcus bromii is a keystone species for the degradation of resis- желудочно-кишечного тракта, широко применяются пробиотики, пребиотики, синбиотики и обогащенные ими функциональные пищевые продукты.

Приведенные практические рекомендации по применению данных субстанций для лечения и профилактики заболеваний гастроэнтерологического профиля у взрослых и детей разработаны для выбора оптимального пробиотического штамма и пребиотика, способствующего предотвращению или более быстрому обратному развитию симптомов определенного заболевания.

tant starch in the human colon. ISME J. 2012;6:1535-43. DOI: $10.1038 /$ ismej.2012.4

13. ГОСТ Р 52349-2005 Продукты пищевые. Продукты пищевые функциональные. Термины и определения (с Изменением № 1). Дата введения 2006-07-01. http:// docs.cntd.ru/document/1200039951 [GOST R 52349-2005 Food products. Functional food products. Terms and definitions (with Amendment No. 1). Date of effect 2006-07$01 \mathrm{http}: / /$ docs.cntd.ru/document/1200039951]

14. Евразийская экономическая комиссия. Единые санитарноэпидемиологические и гигиенические требования к продукции (товарам), подлежащей санитарно-эпидемиологическому надзору (контролю) с изменениями на 10 мая 2018 года (редакция, действующая с 1 июня 2019 года). [Eurasian Economic Commission. Unified Sanitary, Epidemiological and Hygienic Requirements for Products (Goods) Subject to Sanitary and Epidemiological Surveillance (Control), as amended on 10 May, 2018 (Revision effective from 1 June, 2019)] http://www.eurasiancommission.org/ru/ act/texnreg/depsanmer/sanmeri/Pages/P2_299.aspx http://www.eurasiancommission.org/ru/act/texnreg/ depsanmer/sanmeri/Pages/P2_299.aspx

15. Федеральная служба по надзору в сфере защиты прав потребителей и благополучия человека. Что нужно знать о биологически активных добавках к пище. Информационный бюллетень 12.05.2019 г. [Federal Service on Customers' Rights Protection and Human Wellbeing Surveillance. What one needs to know about dietary supplements. Information Bulletin of 12.05.2019. https:// www.rospotrebnadzor.ru/about/info/news/news details. php?ELEMENT_ID=11900] https://www.rospotrebnadzor.ru/about/info/news/news_details.php? ELEMENT $\mathrm{ID}=11900$

16. TP TC $021 / 2011$. Технический регламент Таможенного союза «О безопасности пищевой продукции» от 9 декабря 2011 года № 880 (с изменениями на 8 августа 2019 года). [TR CU 021/2011 Technical Regulation of the Customs Union "On Food Safety" of 9 December, 2011, No. 880 (as amended on 8 August, 2019) http://old.gost.ru/ wps/portal/pages/main] http://old.gost.ru/wps/por$\mathrm{tal} /$ pages/main 
17. Постановление Главного государственного санитарного врача Российской Федерации от 18 февраля 2008 г. № 13 «Об утверждении СанПиН 2.3.2.2340-08». Зареги стрировано Минюстом России 11 марта 2008 г. Регистрационный № 11311. [https://rg.ru/2010/12/30/sanpinsite-dok.html Decree of the Chief Public Health Officer of the Russian Federation of February 18, 2008, No. 13 "On Approval of SanPiN 2.3.2.2340-08". Registered by the Ministry of Justice of Russia on March 11, 2008. Registered No. 11311(In Russ.)] https://rg.ru/2010/12/30/ sanpin-site-dok.html.

18. Федеральный закон РФ от 12 апреля 2010 г. № 61 Ф3 «Об обращении лекарственных средств». [Federal Law of the Russian Federation of 12 April, 2010, No. 61-FZ «On Regulation of Drugs»(In Russ.)] https:// rg.ru/2010/04/14/lekarstva-dok.html

19. Приказ Министерства здравоохранения РФ от 11 июля 2017 г. № 403н «Об утверждении правил отпуска лекарственных препаратов для медицинского применения, в том числе иммунобиологических лекарственных препаратов, аптечными организациями, индивидуальными предпринимателями, имеющими лицензию на фармацевтическую деятельность» от 12 сентября 2017 г. [Order of the Ministry of Health of the Russian Federation No. 403n of 11 July, 2017, "On Approval of Rules for Dispensing Drugs for Medical Use, Including Immunobiological Drugs, by Pharmaceutical Organisations and Individual Entrepreneurs Licensed to Conduct Pharmaceutical Activities" of 12 September, 2017(In Russ.)] https://rg.ru/2017/09/12/minzdrav-prikaz403-sitedok.html

20. Общая фармакопейная статья «Пробиотики» ОФС.1.7. 1.0008.15 Министерства Здравоохранения РФ. [General Pharmacopoeial Article "Probiotics" OFS.1.7.1.0008.15 of the Ministry of Health of the Russian Federation (In Russ.)] http://femb.ru/femb/pharmacopea.php

21. Федеральный закон «О качестве и безопасности пищевых продуктов» от 02.01.2000 г. № 29-Ф3 [Federal Law «On Quality and Safety of Foodstuffs» of 02.01.2000, No. 29-FZ(In Russ.)] URL: https://rg.ru/2000/01/02/ produkty-dok.html.

22. Федеральный закон от 01.03.2020 г. № 47-ФЗ «О внесении изменений в Федеральный закон «О качестве и безопасности пищевых продуктов» и статью 37 Федерального закона «Об образовании в Российской Федерации» [Federal Law No. 47-FZ of 01.03.2020 "On Amendments to the Federal Law 'On Quality and Safety of Food stuffs' and Article 37 of the Federal Law 'On Education in the Russian Federation'” (In Russ.)] URL: https:// rg.ru/2020/03/03/pitanie-dok.html.

23. ГОСТ Р 55577-2013. Национальный стандарт Российской Федерации. Продукты пищевые специализированные и функциональные. Информация об отличительных признаках и эффективности. [GOST P 55577-2013. National Standard of the Russian Federation. Specialised and functional food products. Information on distinguishing characters and efficacy (In Russ.)] URL: https:// internet-law.ru/gosts/gost/55874

24. ГОСТ Р 54059-2010. Национальный стандарт Российской Федерации. Продукты пищевые функциональные. Ингредиенты пищевые функциональные. Классификация и общие требования. [GOST R 54059-2010. National Standard of the Russian Federation. Functional food products. Functional food ingredients. Classification and general requirements (In Russ.)] URL: https://internet-law. $\mathrm{ru} /$ gosts/gost/50895/

25. Shi L.H., Balakrishnan K., Thiagarajah K., Mohd Is mail N.I., Yin O.S. Beneficial Properties of Probiotics. Trop Life Sci Res. 2016;27(2):73-90. DOI: 10.21315/ tlsr2016.27.2.6

26. Ishibashi N., Yamazaki S. Probiotics and safety. Am J Clin Nutr. 2001;73(2 Suppl):465S-470. DOI: 10.1093/ ajcn $/ 73.2 .465 \mathrm{~s}$
27. de Vos P., Faas M.M., Spasojevic M.M., Sikkema J. Encapsulation for preservation of functionality and targeted delivery of bioactive food components. Int Dairy J. 2010;20:292-302. DOI: 10.1016/j.idairyj.2009.11.008

28. Burgain J., Gaiani C., Linder M., Scher J. Encapsulation of probiotic living cells: from laboratory scale to industrial applications. J Food Eng. 2011;104:467-83. DOI: $10.1016 /$ j.jfoodeng.2010.12.031

29. Salas-Jara M., Ilabaca A., Vega M., García A. Biofilm forming Lactobacillus: new challenges for the development of probiotics. Microorganisms. 2016;4(3):35. DOI: 10.3390 /microorganisms 4030035

30. Tsai Y.L., Lin T.L., Chang C.J., Wu T.R., Lai W.F., Lu C.C., Lai H.C. Probiotics, prebiotics and amelioration of diseases. J Biomed Sci. 2019;26(1):3. DOI: 10.1186/ s12929-018-0493-6

31. Howick J., Chalmers I., Glasziou P., Greenhalgh T., Heneghan C., Liberati A., et al. Explanation of the 2011 Oxford Centre for Evidence-Based Medicine (OCEBM) Levels of Evidence (Background Document). Oxford Centre for Evidence-Based Medicine. https://www.cebm. net $/$ index.aspx $? \mathrm{o}=5653$

32. Allen S.J., Martinez E.G., Gregorio G.V., Dans L.F. Probiotics for treating acute infectious diarrhoea. $\mathrm{Co}^{-}$ chrane Database Syst Rev. 2010;(11):CD003048. DOI: 10.1002/14651858.CD003048.pub3

33. Höchter W., Hagenhoff G. Saccharomyces boulardii in acute adult diarrhea: efficacy and tolerability of treatment. Munch Med Wochenschr. 1990;(132):188-92.

34. Grossi E., Buresta R., Abbiati R., Cerutti R., Pro-DIA study group. Clinical trial on the efficacy of a new symbiotic formulation, Flortec, in patients with acute diarrhea: a multicenter, randomized study in primary care. J Clin Gastroenterol. 2010;44 Suppl 1:S35-41. DOI: 10.1097/ MCG.0b013e3181e103f4

35. Hempel S., Newberry S.J., Maher A.R., Wang Z., Miles J.N.V., Shanman R., et al. Probiotics for the prevention and treatment of antibiotic-associated diarrhea: a systematic review and meta-analysis. JAMA. 2012;307(18):1959-69. DOI: 10.1001/jama.2012.3507

36. Ouwehand A.C., Dong-Lian C., Weijian X., Stewart M., Ni J., Stewart T., et al. Probiotics reduce symptoms of antibiotic use in a hospital setting: a randomized dose response study. Vaccine. 2014;32(4):458-63

37. Chatterjee S., Kar P., Das T., Ray S., Gangulyt S., Rajendiran C., et al. Randomised placebocontrolled double blind multicenteric trial on efficacy and safety of Lactobacillus acidophilus LA-5 and Bifidobacterium BB-12 for prevention of antibiotic-associated diarrhoea. J Assoc Physicians India. 2013;61(10):708-12.

38. Hickson M., D'Souza A.L., Muthu N., Rogers T.R., Want S., Rajkumar C., et al. Use of probiotic Lactobacillus preparation to prevent diarrhoea associated with antibiotics: randomised double blind placebo controlled trial. BMJ. 2007;335(7610):80. DOI: 10.1136/bmj.39231.599815.55

39. Cimperman L., Bayless G., Best K., Diligente A., Mordarski B., Oster M., et al. A randomized, double-blind, placebo-controlled pilot study of Lactobacillus reuteri ATCC 55730 for the prevention of antibiotic-associated diarrhea in hospitalized adults. J Clin Gastroenterol. 2011;45(9):7859. DOI: 10.1097/MCG.0b013e3182166a42

40. Goldenberg J.Z., Yap C., Lytoyn L., Lo C.K., Beardsley J., Mertz D., et al. Probiotics for the prevention of Clostridium difficile-associated diarrhea in adults and children. Cochrane Database Syst Rev. 2013;5:CD006095. DOI: $10.1002 / 14651858 . C D 006095 . p u b 4$

41. Lewis S., Burmeister S., Brazier J. Effect of the prebiotic oligofructose on relapse of Clostridium difficile-associated diarrhea: a randomized, controlled study. Clin Gastroenterol Hepatol. 2005;3(5):442-8. DOI: $10.1016 / \mathrm{s} 1542-$ 3565(04)00677-9

42. Shi X., Zhang J., Mo L., Shi J., Qin M., Huang X. Efficacy and safety of probiotics in eradicating $\mathrm{He}^{-}$ licobacter pylori. A network meta-analysisMedicine 
(Baltimore). 2019;98(15):e15180. DOI: 10.1097/ MD.0000000000015180

43. Dang Y., Reinhardt J.D., Zhou X., Zhang G. The ef fect of probiotics supplementation on Helicobacter pylori eradication rates and side effects during eradication therapy: a meta-analysis. PloS One. 2014;9(11):e111030. DOI: 10.1371/journal.pone.0111030

44. Ojetti V., Bruno G., Ainora M.E., Gigante G., Rizzo G., Roccarina D., et al. Impact of Lactobacillus reuteri Supplementation on Anti-Helicobacter pylori Levofloxacin-Based Second-Line Therapy. Gastroenterol Res Pract. 2012;2012:740381. DOI: 10.1155/2012/740381

45. Ли И.А., Сильвестрова С.Ю., Дроздов В.Н. Пробиотик Риофлора Баланс Нео и антихеликобактерная терапия - повышение эффективности лечения за счет снижения нежелательных явлений. Медицинский Сoвет. 2013;10:100-3. [ Li I.A., Silvestrova S.Yu., Drozdov V.N. "Rioflora Balans Neo" probiotic and anti-Helicobacter therapy: increased efficacy at reduced adverse events. Medical Council. 2013;(10):100-3 (In Russ.)]. DOI: $10.21518 / 2079-701 \mathrm{X}-2013-10-100-103$

46. Ducrotté P., Sawant P., Jayanthi $V$. Clinical trial: Lactobacillus plantarum 299v (DSM 9843) improves symptoms of irritable bowel syndrome. World J Gastroenterol. 2012;18(30):4012-8. DOI: 10.3748/wjg.v18.i30.4012

47. Ford A.C., Quigley E.M., Lacy B.E., Lembo A.J., Saito Y.A., Schiller L.R., et al. Efficacy of prebiotics, probiotics, and synbiotics in irritable bowel syndrome and chronic idiopathic constipation: systematic review and meta-analysis. Am J Gastroenterol. 2014;109(10):1547-61; quiz 1546, 1562. DOI: 10.1038/ajg.2014.202

48. Choi C.H., Jo S.Y., Park H.J., Chang S.K., Byeon J.S., Myung S.J. A randomized, double-blind, placebocontrolled multicenter trial of saccharomyces boulardii in irritable bowel syndrome: effect on quality of life. J Clin Gastroenterol. 2011;45(8):679-83. DOI: 10.1097/ MCG.0b013e318204593e

49. Whorwell P.J., Altringer L., Morel J., Bond Y., Charbonneau D., O'Mahony L., et al. Efficacy of an encapsulated probiotic Bifidobacterium infantis 35624 in women with irritable bowel syndrome. Am J Gastroenterol. 2006;101(7):1581-90. DOI: 10.1111/j.1572 0241.2006.00734.x

50. Moayyedi P., Ford A.C., Talley N.J., Cremonini F., Foxx-Orenstein A.E., Brandt L.J., et al. The efficacy of probiotics in the treatment of irritable bowel syndrome: a systematic review. Gut. 2010;59(3):325-32. DOI: 10.1136 /gut.2008.167270

51. Lorenzo-Zúniga V., Llop E., Suárez C., Álvarez B., Abreu L., Espadaler J., et al. I.31, a new combination of probiotics, improves irritable bowel syndrome-related quality of life. World J Gastroenterol. 2014;20(26):870916. DOI: $10.3748 /$ wjg.v20.i26.8709

52. Ivashkin V., Drapkina O., Poluektova Ye., Kuchumova S., Sheptulin A., Shifrin O. The Effect of a Multistrain Probiotic on the Symptoms and Small Intestinal Bacterial Overgrowth in Constipation-predominant Irritable Bowel Syndrome: A Randomized, Simple-blind, Placebo-controlled Trial. American Journal of Clinical Medicine Research. 2015;3(2):18-23. DOI: 10.12691/ajcmr-3-2-1

53. Guyonnet D., Schlumberger A., Mhamdi L., Jakob S., Chassany O. Fermented milk containing Bifidobacterium lactis DN-173 010 improves gastrointestinal well-being and digestive symptoms in women reporting minor digestive symptoms: a randomized, double-blind, parallel, controlled study. British Journal of Nutrition, 2009;102(11):165462. DOI: $10.1111 /$ j.1365-2036.2007.03362.x

54. Jafari E., Vahedi H., Merat S., Momtahen S., Riahi A. Therapeutic effects, tolerability and safety of a multi-strain probiotic in Iranian adults with irritable bowel syndrome and bloating. Arch Iran Med. 2014;17(7):466-70. DOI: $0141707 /$ AIM.003

55. Yang Y.X., He M., Hu G., Wei J., Pages P., Yang X.H., et al. Effect of a fermented milk containing Bifidobacterium lactis DN-173010 on Chinese constipated women.
World J Gastroenterol. 2008;14(40):6237-43. DOI: $10.3748 /$ wjg. 14.6237

56. Ojetti V., Ianiro G., Tortora A., D’Angelo G., Di Rienzo T.A., Bibbò S., et al. The effect of Lactobacillus reuteri supplementation in adults with chronic functional constipation: a randomized, double-blind, placebo-controlled trial. J Gastrointest Liver Dis JGLD. 2014;23(4):387-91. DOI: $10.15403 /$ jgld.2014.1121.234.elr

57. Schumann C. Medical, nutritional and technological properties of lactulose. An update. Eur J Nutr. 2002;41 Suppl 1:I17-25. DOI: $10.1007 / \mathrm{s} 00394-002-1103-6$

58. Nyman $M$. Fermentation and bulking capacity of indigestible carbohydrates: the case of inulin and oligofructose. Br J Nutr. 2002;87 Suppl 2:S163-8. DOI: 10.1079/BJNBJN $/ 2002533$

59. Eales J., Gibson P.R., Whorwell P.J., Kellow J., Yellowlees A., Perry R., et al. Systematic review and metaanalysis: the effects of fermented milk with Bifidobacterium lactis CNCM I-2494 and lactic acid bacteria on gastrointestinal discomfort in the general adult population. Therap Adv Gastroenterol. 2017;10(1):74-88. DOI: $10.1177 / 1756283 X 16670075$

60. Gluud L.L., Vilstrup H., Morgan M.Y. Non-absorbable disaccharides versus placebo/no intervention and lactulose versus lactitol for the prevention and treatment of hepatic encephalopathy in people with cirrhosis. Cochrane Database Syst Rev. 2016;4:CD003044. DOI: 10.1002/14651858. CD003044.pub3

61. Szajewska H., Guarino A., Hojsak I., Indrio F., Kolacek S., Shamir R., et al.; European Society for Pediatric Gastroenterology, Hepatology, and Nutrition. Use of probiotics for management of acute gastroenteritis: a position paper by the ESPGHAN Working Group for Probiotics and Prebiotics. J Pediatr Gastroenterol Nutr. 2014:58(4):531-9. DOI: 10.1097/MPG.0000000000000320

62. Szajewska H., Skórka A., Ruszczyński M., GieruszczakBiałek D. Meta-analysis: Lactobacillus GG for treating acute gastroenteritis in children--updated analysis of randomised controlled trials. Aliment Pharmacol Ther. 2013;38(5):467-76. DOI: 10.1111/apt.12403

63. Szajewska H., Skórka A. Saccharomyces boulardii for treating acute gastroenteritis in children: updated metaanalysis of randomized controlled trials. Aliment Pharmacol Ther. 2009;30(9):960-1. DOI: 10.1111/j.13652036.2009.04113.x

64. Szajezoska H., Kołodziej M. Systematic review with metaanalysis: Lactobacillus rhamnosus GG in the prevention of antibiotic-associated diarrhoea in children and adults. Aliment Pharmacol Ther. 2015;42(10):1149-57. DOI: 10.1111 /apt.13404

65. Pedone C.A., Arnaud C.C., Postaire E.R., Bouley C.F., Reinert $P$. Multicentric study of the effect of milk fermented by Lactobacillus casei on the incidence of diarrhoea. Int J Clin Pract. 2000;54(9):568-71.

66. Agustina R., Kok F.J., van de Rest O., Fahmida U., Firmansyah A., Lukito W., et al. Randomized trial of probiotics and calcium on diarrhea and respiratory tract infections in Indonesian children. Pediatrics. 2012;129(5):e1155-64. DOI: $10.1542 /$ peds. 2011-1379

67. Gutierrez-Castrellon P., Lopez-Velazquez G., DiazGarcia L., Jimenez-Gutierrez C., Mancilla-Ramirez J., Estevez-Jimenez J., et al. Diarrhea in preschool children and Lactobacillus reuteri: a randomized controlled trial. Pediatrics. 2014;133(4):e904-9. DOI: 10.1542/ peds. 2013-0652

68. Szajezoska H., Horvath A., Kołodziej M. Systematic review with meta-analysis: Saccharomyces boulardii supplementation and eradication of Helicobacter pylori infection. Aliment Pharmacol Ther. 2015;41(12):1237-45. DOI: $10.1111 /$ apt.13214

69. Sykora J., Valeckova K., Amlerova J., Siala K., Dedek P., Watkins $S$., et al. Effects of a specially designed fermented milk product containing probiotic Lactobacillus casei DN-114 001 and the eradication of $\mathrm{H}$. pylori in children: a prospective randomised double-blind study. J 
Clin Gastroenterol. 2005;39(8):692-8. DOI: 10.1097/01. mcg.0000173855.77191.44

70. Urbańska M., Szajewska $H$. The efficacy of Lactobacillus reuteri DSM 17938 in infants and children: a review of the current evidence. Eur J Pediatr. 2014;173(10):1327-37. DOI: $10.1007 / \mathrm{s} 00431-014-2328-0$

\section{Сведения об авторах}

Ивашкин Владимир Трофимович - доктор медицинских наук, академик РАН, профессор, заведующий кафедрой пропедевтики внутренних болезней, гастроэнтерологии и гепатологии Института клинической медицины им. Н.В. Склифосовского ФГАОУ ВО «Первый Московский государственный медицинский университет им. И.М. Сеченова» (Сеченовский Университет).

Контактная информация: kont07@mail.ru;

119991, г. Москва, ул. Погодинская, д. 1, стр. 1.

ORCID: https://orcid.org/0000-0002-6815-6015

Маев Игорь Вениаминович - доктор медицинских наук, академик РАН, профессор, заведующий кафедрой пропедевтики внутренних болезней и гастроэнтерологии ФГБОУ ВО «Московский государственный медико-стоматологический университет им. А.И. Евдокимова».

Контактная информация: igormaev@rambler.ru;

127473, г. Москва, ул. Делегатская, д. 20, стр. 1.

ORCID: https://orcid.org/0000-0001-6114-564X

Абдулганиева Диана Ильдаровна - доктор медицинских наук, зав. кафедрой госпитальной терапии ФГБОУ ВО «Казанский государственный медицинский университет».

Контактная информация: Diana_s@mail.ru;

420012, г. Казань, ул. Бутлерова, д. 49.

ORCID: https://orcid.org/0000-0001-7069-2725

Алексеенко Сергей Алексеевич - доктор медицинских наук, заведующий кафедрой госпитальной терапии Дальневосточного государственного медицинского университета (ДВГМУ), руководитель Клиники внутренних болезней Дорожной клинической больницы на ст. Хабаровск-1 Дальневосточной железной дороги (ДВЖД).

Контактная информация: sa.alexeenko@gmail.com;

680000 , г. Хабаровск, ул. Запарина, д. 83.

ORCID: https://orcid.org/0000-0003-1724-9980

Горелов Александр Васильевич - доктор медицинских наук, член-корреспондент РАН, профессор, заместитель директора по научной работе ФБУН «Центральный НИИ эпидемиологии» Роспотребнадзора, профессор кафедры детских болезней Института здоровья детей им. Н.Ф. Филатова ФГАОУ ВО «Первый Московский государственный медицинский университет им. И.М. Сеченова» (Сеченовский Университет).

Контактная информация: zdn@pcr.ru;

111123, г. Москва, ул. Новогиреевская д. За.

ORCID: https://orcid.org/ 0000-0001-9257-0178

Захарова Ирина Николаевна - доктор медицинских наук, профессор, заведующая кафедрой педиатрии им. акад. Г.Н. Сперанского ФГБОУ ДПО «Российская медицинская академия непрерывного профессионального образования». Контактная информация: 79166020368@yandex.ru;

г. Москва, улица Героев Панфиловцев, д. 28.

ORCID: https://orcid.org/0000-0003-4200-4598
71. Horvath A., Dziechciarz P., Szajewska H. Meta-analysis: Lactobacillus rhamnosus GG for abdominal pain-related functional gastrointestinal disorders in childhood. Aliment Pharmacol Ther. 2011;33(12):1302-10. DOI: 10.1111/j.1365-2036.2011. 04665.x

\section{Information about the authors}

Vladimir T. Ivashkin - Dr. Sci. (Med.), RAS Academician, Prof., Departmental Head, Department of Propaedeutics of Internal Diseases, N.V. Sklifosovsky Institute of Clinical Medicine, Sechenov First Moscow State Medical University (Sechenov University).

Contact information: kont07@yandex.ru;

119435, Moscow, Pogodinskaya str., 1, bld. 1.

ORCID: https://orcid.org/0000-0002-6815-6015

Igor V. Maev - Dr. Sci. (Med.), Full Member of the Russian Academy of Sciences, Prof., Head of the Chair of Internal Disease Propaedeutics and Gastroenterology, Yevdokimov Moscow State University of Medicine and Dentistry.

Contact information: igormaev@rambler.ru;

127473, Moscow, Delegatskaya str., 20, bld. 1.

ORCID: https://orcid.org/0000-0001-6114-564X

Diana I. Abdulganieva - Dr. Sci. (Med.), Head of the Chair of Hospital Therapy, Kazan State Medical University.

Contact information: Diana_s@mail.ru;

420012, Kazan, Butlerova str., 49.

ORCID: https://orcid.org/0000-0001-7069-2725

Sergey A. Alekseenko - Dr. Sci. (Med.), Head of the Chair of Hospital Therapy, Far-Eastern State Medical University; Head of the Internal Medicine Clinic, Khabarovsk-1 Railway Station Clinical Hospital, Far-Eastern Railways.

Contact information: sa.alexeenko@gmail.com; 680000, Khabarovsk, Zaparina str., 83.

ORCID: https://orcid.org/0000-0003-1724-9980

Alexander V. Gorelov - Dr. Sci. (Med.), Corresponding Member of the Russian Academy of Sciences, Prof., Deputy Director for Science, Central Research Institute of Epidemiology; Prof., Chair of Infant Diseases, Filatov Institute of Children's Health, Sechenov First Moscow State Medical University (Sechenov University).

Contact information: zdn@pcr.ru;

111123, Moscow, Novogireevskaya str., 3a.

ORCID: https://orcid.org/ 0000-0001-9257-0178

Irina N. Zakharova - Dr. Sci. (Med.), Prof., Head of the Chair of Paediatrics named after Acad. G.N. Speranskiy, Russian Medical Academy of Continuous Professional Education. Contact information: 79166020368@yandex.ru; Moscow, Geroev Panfilovtsev str., 28.

ORCID: https://orcid.org/0000-0003-4200-4598 
Зольникова Оксана Юрьевна - доктор медицинских наук, доцент кафедры пропедевтики внутренних болезней, гастроэнтерологии и гепатологии Института клинической медицины им. Н.В. Склифосовского ФГАОУ ВО «Первый Московский государственный медицинский университет им. И.М. Сеченова» (Сеченовский Университет).

Контактная информация: ks.med@mail.ru;

119991, г. Москва, ул. Погодинская, д. 1, стр. 1.

ORCID: https://orcid.org/0000-0002-6701-789X

Ивашкина Наталья Юрьевна - доктор медицинских наук, доцент кафедры пропедевтики внутренних болезней и гастроэнтерологи ФГБОУ ВО «Московский государственный медико-стоматологический университет им. А.И. Евдокимова». Контактная информация: akliha@bk.ru; 127473, г. Москва, ул. Делегатская, д. 20, стр. 1 ORCID: https://orcid.org/0000-0002-0847-9234

Корочанская Наталья Всеволодовна - доктор медицин ских наук, профессор кафедры хирургии № 3 ФГБОУ ВО «Кубанский государственный медицинский университет»; руководитель гастроэнтерологического центра ГБУЗ «Краевая клиническая больница № 2».

Контактная информация: nvk-gastro@mail.ru;

350063, г. Краснодар, ул. им. Митрофана Седина, д. 4.

ORCID: https://orcid.org/0000-0002-5538-9419

Маммаев Сулейман Нураттинович - доктор медицинских наук, профессор, заведующий кафедрой госпитальной терапии № 1, ректор ФГБОУ ВО «Дагестанский государственный медицинский университет».

Контактная информация: hepar-sul-dag@mail.ru,

367000, Республика Дагестан, г. Махачкала, пл. Ленина, д. 1. ORCID: https://orcid.org/0000-0001-8898-8831

Полуэктова Елена Александровна - доктор медицинских наук, профессор кафедры пропедевтики внутренних болезней, гастроэнтерологии и гепатологии Института клинической медицины им. Н.В. Склифосовского ФГАОУ ВО «Первый Московский государственный медицинский университет им. И.М. Сеченова» (Сеченовский Университет). Контактная информация: polouektova@rambler.ru; 119991, г. Москва, ул. Погодинская, д. 1, стр. 1. ORCID: https://orcid.org/0000-0003-1312-120X

Трухманов Александр Сергеевич - доктор медицинских наук, профессор кафедры пропедевтики внутренних болезней, гастроэнтерологии и гепатологии Института клинической медицины им. Н.В. Склифосовского ФГАОУ ВО «Первый Московский государственный медицинский университет им. И.М. Сеченова» (Сеченовский Университет). Контактная информация: alexander.trukhmanov@gmail.com; 119991, г. Москва, ул. Погодинская, д. 1, стр. 1.

ORCID: https://orcid.org/0000-0003-3362-2968

Усенко Денис Валериевич - доктор медицинских наук, ведущий научный сотрудник клинического отдела инфекционной патологии ФБУН «Центральный НИИ эпидемиологии» Роспотребнадзора.

Контактная информация: dusenko@rambler.ru;

111123, г. Москва, ул. Новогиреевская д. За.

ORCID: https://orcid.org/ 0000-0001-5232-7337
Oxana Yu. Zolnikova - Dr. Sci. (Med.), Assoc. Prof., Chair of Internal Disease Propaedeutics, Gastroenterology and Hepatology, Sklifosovsky Institute of Clinical Medicine, Sechenov First Moscow State Medical University (Sechenov University). Contact information: ks.med@mail.ru;

119991, Moscow, Pogodinskaya str., 1, bld. 1.

ORCID: https://orcid.org/0000-0002-6701-789X

Natalia Yu. Ivashkina - Dr. Sci. (Med.), Assoc. Prof., Chair of Internal Disease Propaedeutics and Gastroenterology, Yevdokimov Moscow State University of Medicine and Dentistry. Contact information: akliha@bk.ru;

127473, Moscow, Delegatskaya str. 20, bld. 1.

ORCID: https://orcid.org/0000-0002-0847-9234

Natalia V. Korochanskaya - Dr. Sci. (Med.), Prof., Chair of Surgery No. 3, Kuban State Medical University; Head of the Centre for Gastroenterology, Territorial Clinical Hospital No. 2.

Contact information: nvk-gastro@mail.ru;

350063, Krasnodar, Mitrofana Sedina str., 4.

ORCID: https://orcid.org/0000-0002-5538-9419

Suleyman N. Mammayev - Dr. Sci. (Med.), Prof., Head of the Chair of Hospital Therapy No. 1; Rector of the Dagestan State Medical University.

Contact information: hepar-sul-dag@mail.ru,

367000, Republic of Dagestan, Makhachkala, Lenina sq., 1.

ORCID: https://orcid.org/0000-0001-8898-8831

Elena A. Poluektova - Dr. Sci. (Med.), Prof., Chair of Internal Disease Propaedeutics, Gastroenterology and Hepatology, Sklifosovsky Institute of Clinical Medicine, Sechenov First Moscow State Medical University (Sechenov University).

Contact information: polouektova@rambler.ru; 119991, Moscow, Pogodinskaya str., 1, bld. 1. ORCID: https://orcid.org/0000-0003-1312-120X

Alexander S. Trukhmanov - Dr. Sci. (Med.), Prof., Chair of Internal Disease Propaedeutics, Gastroenterology and Hepatology, Sklifosovsky Institute of Clinical Medicine, Sechenov First Moscow State Medical University (Sechenov University). Contact information: alexander.trukhmanov@gmail.com; 119991, Moscow, Pogodinskaya str., 1, bld. 1.

ORCID: https://orcid.org/0000-0003-3362-2968

Denis V. Usenko - Dr. Sci. (Med.), Leading Researcher, Clinical Department of Infectious Pathology, Central Research Institute of Epidemiology.

Contact information: dusenko@rambler.ru;

111123, Moscow, Novogireevskaya str., 3a.

ORCID: https://orcid.org/ 0000-0001-5232-7337 
Успенский Юрий Павлович - профессор, доктор медицинских наук, заведующий кафедрой факультетской терапии им. профессора В.А. Вальдмана ФГБОУ ВО «Санкт-Петербургский государственный педиатрический медицинский университет».

Контактная информация: uspenskiy65@mail.ru;

194100, Санкт-Петербург, ул. Литовская, д. 2.

ORCID: https://orcid.org/0000-0001-6434-1267

Цуканов Владислав Владимирович - профессор, доктор медицинских наук, заведующий Клиническим отделением патологии пищеварительной системы у взрослых и детей ФБГНУ «Федеральный исследовательский центр “Красноярский научный центр Сибирского отделения Российской академии наук”», обособленное подразделение НИИ медицинских проблем Севера.

Контактная информация: gastro@impn.ru;

660022, г. Красноярск, ул. Партизана Железняка, д. Зг.

ORCID: https://orcid.org/0000-0002-9980-2294

Шифрин Олег Самуилович - доктор медицинских наук, профессор кафедры пропедевтики внутренних болезней, гастроэнтерологии и гепатологии Института клинической медицины им. Н.В. Склифосовского, заведующий отделением хронических заболеваний кишечника и поджелудочной железы клиники пропедевтики внутренних болезней, гастроэнтерологии и гепатологии им. В.Х. Василенко ФГАОУ ВО «Первый Московский государственный медицинский университет им. И.М. Сеченова» (Сеченовский Университет). Контактная информация: oleg_shifrin@mail.ru; 119991, г. Москва, ул. Погодинская, д. 1, стр. 1. ORCID: https://orcid.org/0000-0001-8148-2862

Бережная Ирина Владимировна - кандидат медицинских наук, доцент кафедры педиатрии им. акад. Г.Н. Сперанского ФГБОУ ДПО «Российская медицинская академия непрерывного профессионального образования».

Контактная информация: berezhnaya-irina26@yandex.ru;

г. Москва, улица Героев Панфиловцев 28.

ORCID: https://orcid.org/0000-0001-5684-7575

Ивашкин Константин Владимирович - кандидат медицинских наук, доцент кафедры пропедевтики внутренних болезней, гастроэнтерологии и гепатологии Института клинической медицины им. Н.В. Склифосовского ФГАОУ ВО «Первый Московский государственный медицинский университет им. И.М. Сеченова» (Сеченовский Университет). Контактная информация: ivashkin_k_v_1@staff.sechenov.ru; 119991, г. Москва, ул. Погодинская, д. 1, стр. 1.

ORCID: https://orcid.org/0000-0002-5699-541X

Лапина Татьяна Львовна - кандидат медицинских наук, доцент кафедры пропедевтики внутренних болезней, гастроэнтерологии и гепатологии Института клинической медицины им. Н.В. Склифосовского ФГАОУ ВО «Первый Московский государственный медицинский университет им. И.М. Сеченова» (Сеченовский Университет).

Контактная информация: tatlapina@gmail.com;

119991, г. Москва, ул. Погодинская, д. 1, стр. 1.

ORCID: https://orcid.org/0000-0003-4456-8725

Масленников Роман Вячеславович - кандидат медицинских наук, ассистент кафедры пропедевтики внутренних болезней, гастроэнтерологии и гепатологии Института клинической медицины им. Н.В. Склифосовского ФГАОУ ВО «Первый Московский государственный медицинский университет им. И.М. Сеченова» (Сеченовский Университет). Контактная информация: mmmm00@yandex.ru; 119991, г. Москва, ул. Погодинская, д. 1, стр. 1. ORCID: https://orcid.org/0000-0001-7513-1636
Yury P. Uspensky - Dr. Sci. (Med.), Prof., Head of the Chair of Faculty Therapy named after Prof. V.A. Valdman, Saint-Petersburg State Pediatric Medical University.

Contact information: uspenskiy65@mail.ru;

194100, St. Petersburg, Litovskaya str., 2.

ORCID: https://orcid.org/0000-0001-6434-1267

Vladislav V. Tsukanov - Dr. Sci. (Med.), Prof., Head of the Clinical Department of Adult and Infant Digestive Pathology, Research Institute for Medical Problems in the North - Division of Krasnoyarsk Scientific Centre of the Siberian Branch of the RAS.

Contact information: gastro@impn.ru;

660022, Krasnoyarsk, Partizana Zheleznyaka str., 3Г.

ORCID: https://orcid.org/0000-0002-9980-2294.

Oleg S. Shifrin - Dr. Sci. (Med.), Prof., Chair of Internal Disease Propaedeutics, Gastroenterology and Hepatology, Sklifosovsky Institute of Clinical Medicine; Head of the Department of Chronic Intestinal and Pancreatic Diseases, Vasilenko Clinic of Internal Disease Propaedeutics, Gastroenterology and Hepatology, Sechenov First Moscow State Medical University (Sechenov University).

Contact information: oleg_shifrin@mail.ru;

119991, Moscow, Pogodinskaya str., 1, bld. 1

ORCID: https://orcid.org/0000-0001-8148-2862

Irina V. Berezhnaya - Cand. Sci. (Med.), Assoc. Prof., Chair of Paediatrics named after Acad. G.N. Speranskiy, Russian Medical Academy of Continuous Professional Education.

Contact information: berezhnaya-irina26@yandex.ru;

Moscow, Geroev Panfilovtsev str., 28.

ORCID: https://orcid.org/0000-0001-5684-7575

Konstantin V. Ivashkin - Cand. Sci. (Med.), Assoc. Prof., Chair of Internal Disease Propaedeutics, Gastroenterology and Hepatology, Sklifosovsky Institute of Clinical Medicine, Sechenov First Moscow State Medical University (Sechenov University).

Contact information: ivashkin k k_v_1@staff.sechenov.ru;

119991, Moscow, Pogodinskaya str., 1, bld. 1.

ORCID: https://orcid.org/0000-0002-5699-541X

Tatiana L. Lapina - Cand. Sci. (Med.), Assoc. Prof., Chair of Internal Disease Propaedeutics, Gastroenterology and Hepatology, Sklifosovsky Institute of Clinical Medicine, Sechenov First Moscow State Medical University (Sechenov University). Contact information: tatlapina@gmail.com;

119991, Moscow, Pogodinskaya str., 1, bld. 1.

ORCID: https://orcid.org/0000-0003-4456-8725

Roman V. Maslennikov - Cand. Sci. (Med.), Research Assistant, Chair of Internal Disease Propaedeutics, Gastroenterology and Hepatology, Sklifosovsky Institute of Clinical Medicine, Sechenov First Moscow State Medical University (Sechenov University).

Contact information: mmmm00@yandex.ru;

119991, Moscow, Pogodinskaya str., 1, bld. 1.

ORCID: https://orcid.org/0000-0001-7513-1636 
Николаева Светлана Викторовна - кандидат медицинских наук, старший научный сотрудник клинического отдела инфекционной патологии ФБУН «Центральный НИИ эпидемиологии».

Контактная информация: nikolaeva008@list.ru;

111123, г. Москва, ул. Новогиреевская д. За.

ORCID: https://orcid.org/ 0000-0003-3880-8112

Сугян Наринэ Григорьевна - кандидат медицинских наук, доцент кафедры педиатрии им. академика Г.Н. Сперанского ФГБОУ ДПО «Российская медицинская академия непрерывного профессионального образования».

Контактная информация: narine6969@mail.ru;

г. Москва, улица Героев Панфиловцев, д. 28.

ORCID: https://orcid.org/0000-0002-2861-5619

Ульянин Анатолий Игоревич* - врач отделения хронических заболеваний кишечника и поджелудочной железы клиники пропедевтики внутренних болезней, гастроэнтерологии и гепатологии им. В.Х. Василенко ФГАОУ ВО «Первый Московский государственный медицинский университет им. И.М. Сеченова» (Сеченовский Университет).

Контактная информация: dr.ulianin@gmail.com;

119991, г. Москва, ул. Погодинская, д. 1, стр. 1.

ORCID: https://orcid.org/0000-0001-5506-5555
Svetlana V. Nikolaeva - Cand. Sci. (Med.), Senior Researcher, Clinical Department of Infectious Pathology, Central Research Institute of Epidemiology.

Contact information: nikolaeva008@list.ru;

111123, Moscow, Novogireevskaya str., 3a.

ORCID: https://orcid.org/ 0000-0003-3880-8112

Narine G. Sugyan - Cand. Sci. (Med.), Assoc. Prof., Chair of Paediatrics named after Acad. G.N. Speranskiy, Russian Medical Academy of Continuous Professional Education.

Contact information: narine6969@mail.ru;

Moscow, Geroev Panfilovtsev str., 28.

ORCID: https://orcid.org/0000-0002-2861-5619

Anatoly I. Ulyanin* - Physician, Department of Chronic Intestinal and Pancreatic Diseases, Vasilenko Clinic of Internal Disease Propaedeutics, Gastroenterology and Hepatology, Sechenov First Moscow State Medical University (Sechenov University).

Contact information: dr.ulianin@gmail.com;

119991, Moscow, Pogodinskaya str., 1, bld. 1.

ORCID: https://orcid.org/0000-0001-5506-5555

Поступила: 17.03.2021 Принята: 05.04.2021 Опубликована: 30.04.2021 Submitted: 17.03.2021 Accepted: 05.04.2021 Published: 30.04.2021

* Автор, ответственный за переписку / Corresponding author 